\title{
Lokale overheid en populatiegericht gezondheidsbeleid
}

Citation for published version (APA):

Jansen, M. W. J. (2015). Lokale overheid en populatiegericht gezondheidsbeleid. Maastricht University. https://doi.org/10.26481/spe.20150424mj

Document status and date:

Published: 24/04/2015

DOI:

10.26481/spe.20150424mj

Document Version:

Publisher's PDF, also known as Version of record

\section{Please check the document version of this publication:}

- A submitted manuscript is the version of the article upon submission and before peer-review. There can be important differences between the submitted version and the official published version of record.

People interested in the research are advised to contact the author for the final version of the publication, or visit the DOI to the publisher's website.

- The final author version and the galley proof are versions of the publication after peer review.

- The final published version features the final layout of the paper including the volume, issue and page numbers.

Link to publication

\footnotetext{
General rights rights.

- You may freely distribute the URL identifying the publication in the public portal. please follow below link for the End User Agreement:

www.umlib.nl/taverne-license

Take down policy

If you believe that this document breaches copyright please contact us at:

repository@maastrichtuniversity.nl

providing details and we will investigate your claim.
}

Copyright and moral rights for the publications made accessible in the public portal are retained by the authors and/or other copyright owners and it is a condition of accessing publications that users recognise and abide by the legal requirements associated with these

- Users may download and print one copy of any publication from the public portal for the purpose of private study or research.

- You may not further distribute the material or use it for any profit-making activity or commercial gain

If the publication is distributed under the terms of Article $25 \mathrm{fa}$ of the Dutch Copyright Act, indicated by the "Taverne" license above, 
Prof. Dr. Ir. Maria Jansen

Faculty of Health, Medicine and Life Sciences

\section{Lokale overheid en populatiegericht gezondheidsbeleid}


Maastricht University $\cdots$ Laming!

\section{Lokale overheid en} populatiegericht gezondheidsbeleid Prof. Dr. Ir. Maria Jansen Caphri school for Public Hoalth

\section{1}
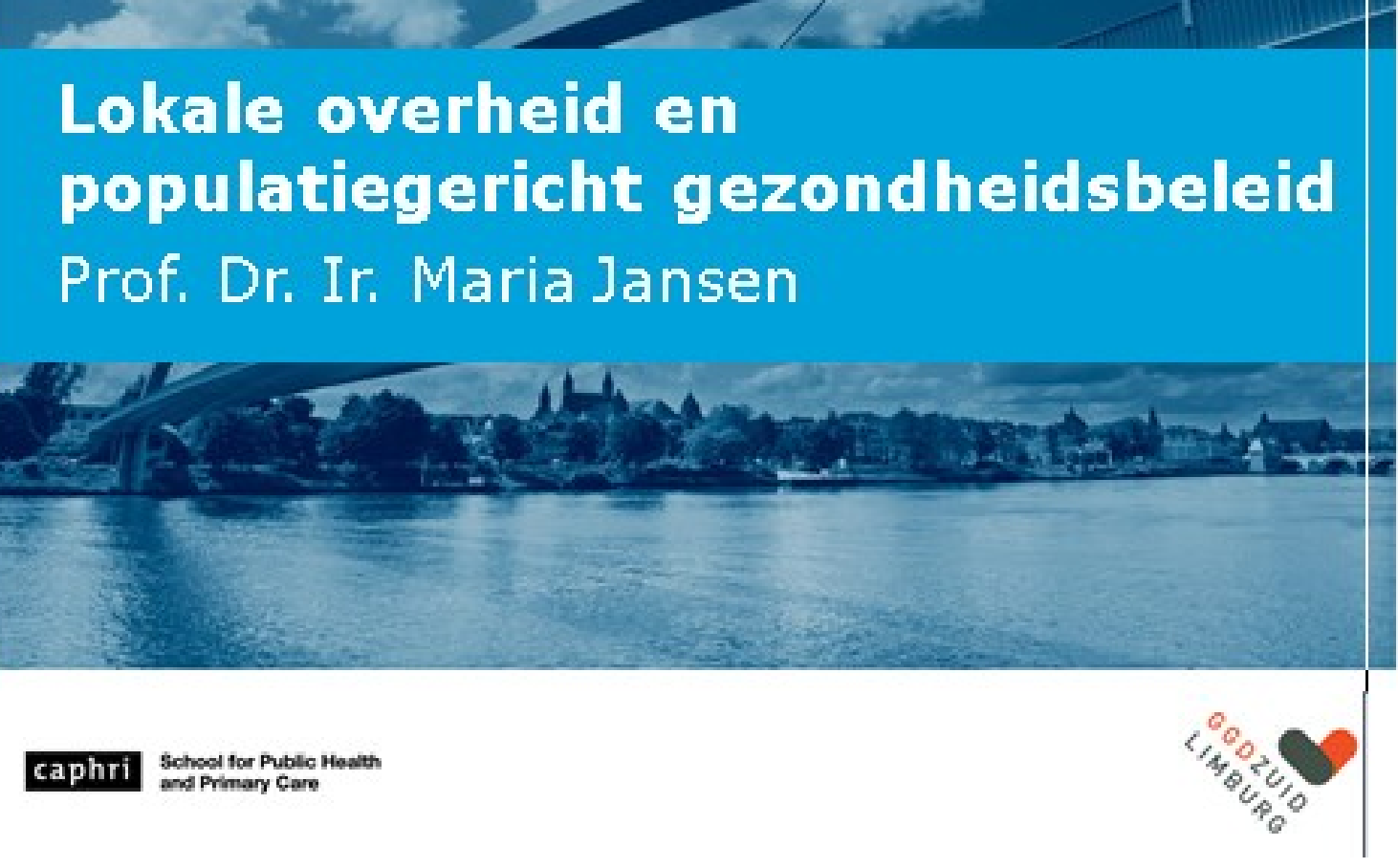


\section{Lokale overheid en populatiegericht gezondheidsbeleid}

Colofon: Tekst Maria Jansen, druk Maastricht University; dia's: Science Vision

ISBN: 978-90-823808-1-1

Alle rechten voorbehouden. Niets uit deze uitgave mag worden verveelvoudigd, opgeslagen in een geautomatiseerd gegevensbestand of openbaar worden gemaakt, zonder voorafgaande schriftelijke toestemming van de auteur of uitgever.

Rede uitgesproken bij de aanvaarding van het ambt van bijzonder hoogleraar populatiegericht gezondheidsbeleid aan de Faculty of Health, Medicine and Life Sciences van de Universiteit Maastricht.

Maastricht, 24 april 2015

Prof. dr. ir. Maria Jansen

Mijnheer de Rector Magnificus, mijnheer de Pro-rector, geacht College van Bestuur van de Universiteit Maastricht, leden van het College van Toezicht, hooggeleerde gasten, leden van het Algemeen Bestuur van de GGD, beste collega's, vrienden, familie en overige aanwezigen. Hartelijk dank voor uw komst naar Maastricht. Fijn dat u hier allen bent vandaag.

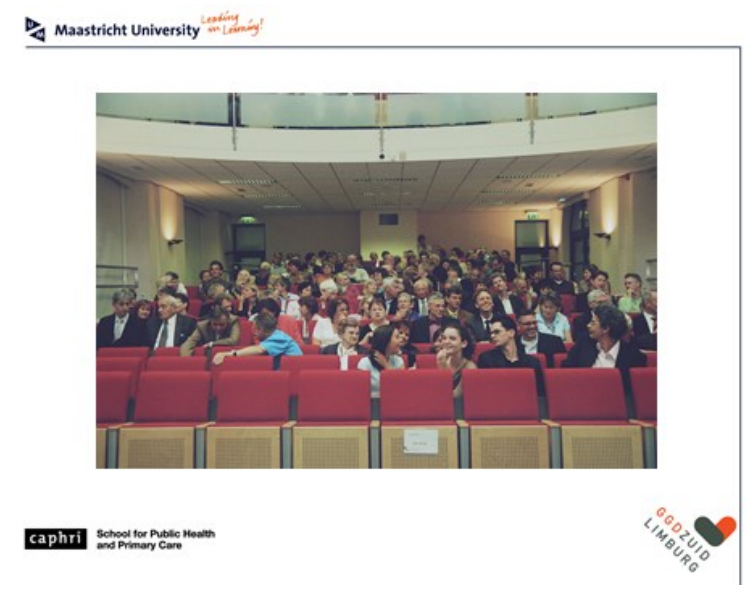

$U$ ziet er allemaal heel goed en feestelijk uit. $U$ bent waarschijnlijk vanochtend welgemutst vertrokken vanuit Groningen, Amsterdam, Utrecht, Nijmegen, Druten, Wijchen, ja vanuit London zelfs naar Maastricht. Fit genoeg om de reis te kunnen maken. Maar ongetwijfeld zitten er mensen in de zaal met een chronische ziekte in lichaam of geest.

Als u een afspiegeling zou zijn van het Nederlandse volk zou 1 op de 14 hier aanwezig last hebben van artrose, 1 op de 20 van diabetes en 1 op de 21 zou moeite hebben met het gehoor; de 3 meest voorkomende aandoeningen in Nederland (RIVM, 2015a). Toch bent $u$ hier en ik prijs mij daar gelukkig mee. Want ook al hebt $u$ wat onder de leden, dat wil nog niet zeggen dat u zich ziek voelt. Integendeel, u functioneert naar tevredenheid in het dagelijkse doen. En als ik u zou vragen: hoe voelt u zich zou driekwart van u zeggen: prima, gezond. Gezondheid is dus meer dan de afwezigheid van ziekte. En als ik u zo zie, schat ik in dat u nog een behoorlijk aantal goede jaren hebt te gaan. 


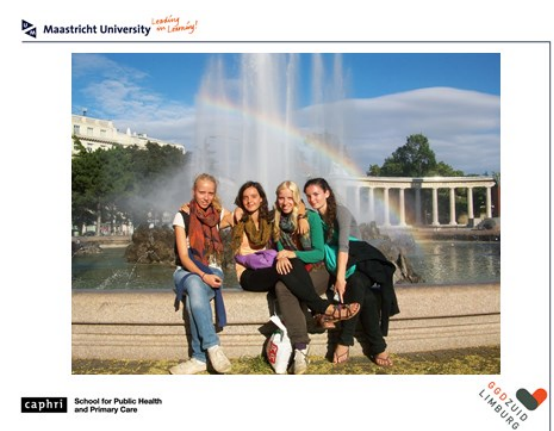

Dat geldt zeker voor de jonge mensen hier in de zaal want de gemiddelde levensverwachting gerekend vanaf de geboorte is voor mannen 79,1 jaar en voor vrouwen 82,8 jaar (RIVM, 2015b).

Er is één maar: $u$ bent geen afspiegeling van het Nederlandse volk. $U$ bent zeer waarschijnlijk gemiddeld genomen hoger opgeleid. En dat maakt wat uit! Vooral in de langdurige beperkingen en de ervaren gezondheid.

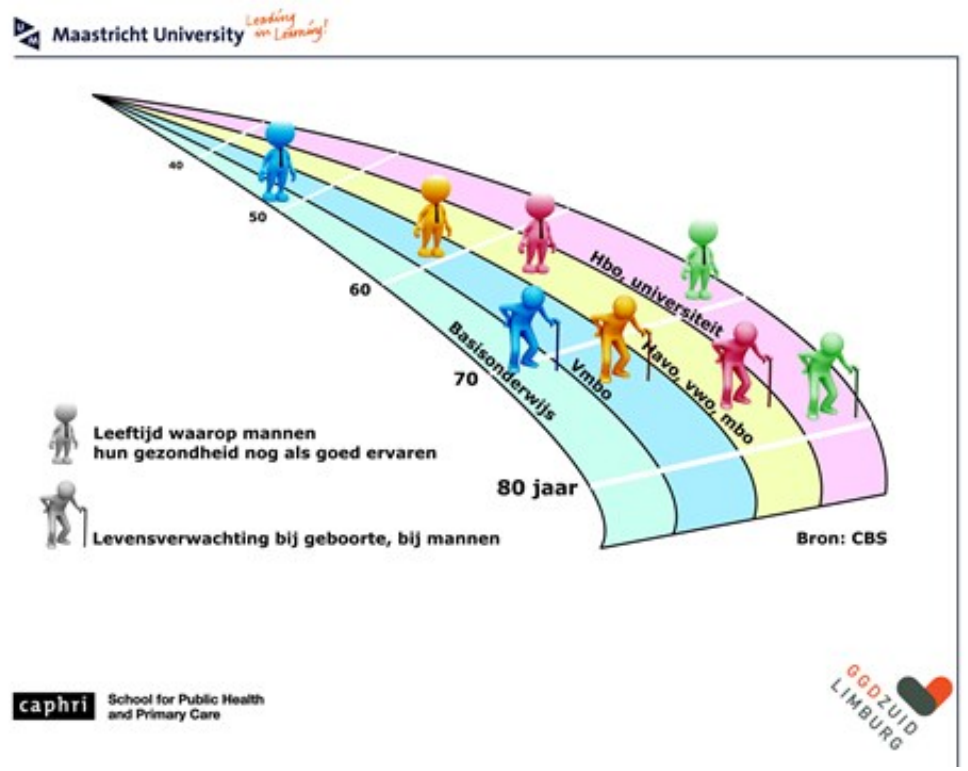

Zo overlijden laagopgeleiden gemiddeld genomen 6 tot 6,5 jaar eerder dan de hoogopgeleiden. In 2008 stond dat nog op een verschil van 3,5 jaar. In dat kortere leven hebben laagopgeleiden 18 tot 19 jaar langer te maken met allerlei ervaren gezondheidsklachten. In 2008 was dat verschil ongeveer 12 jaar. Deze dia illustreert dat. De rechtop staande mannetjes gaan over de gezonde levensverwachting, dus zonder aandoeningen, de krom gebukte mannetjes geven de leeftijd weer waarop men sterft. Voor vrouwen geldt ongeveer hetzelfde (RIVM, 2015b).

Het vakgebied waar ik mij in begeef gaat over die gezonde levensverwachting en daar ga ik het de komende drie kwartier met u over hebben. 


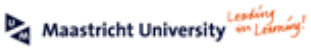

\section{Lokale overheid en populatiegericht gezondheidsbeleid}

De publieke gezondheidszorg

Kenmerken van een populatie

Zorgen voor gezondheid van de populatie

Van gezondheid naar

maatschappelijke participatie

De mogelijkheden van gemeenten, nu en in de toekomst

Mijn betoog bouw ik als volgt op: ik laat $u$ kennismaken met mijn vakgebied: de publieke gezondheidszorg. Vervolgens benoem ik de kenmerken van een populatiegerichte aanpak en ik ga in op de betekenis van gezondheid en de verschuiving die momenteel gaande is. Tot slot laat ik $u$ zien welke mogelijkheden gemeenten hebben om hun burgers gezond en maatschappelijk actief te houden, ook in de toekomst. Ik doe dit op een publieksvriendelijke manier, met zo min mogelijk wetenschappelijk jargon.

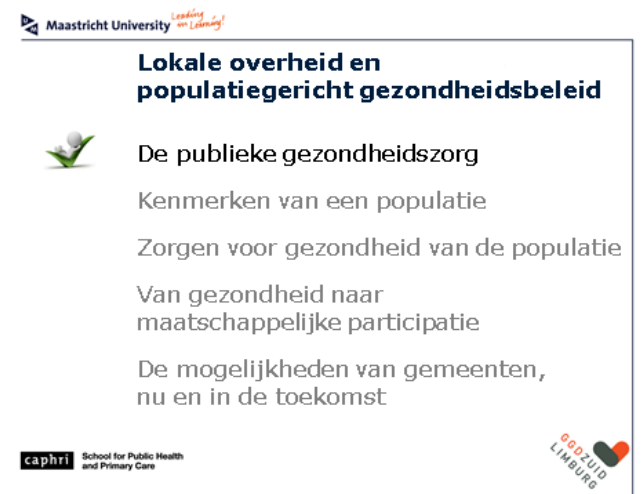

Ik houd mij al jaren bezig met de publieke

gezondheidszorg. Dat is de zorg voor het gezond houden van het publiek, van het volk, van u en ik, van alle burgers. We noemen het ook wel volksgezondheidsbeleid. Het gaat hier dus om beleid dat door de overheid wordt uitgevoerd. Eind $19^{\mathrm{e}}$ en begin $20^{\mathrm{e}}$ eeuw is dit beleid in Nederland gemeengoed geworden. Voorbeelden uit die beginjaren zijn vooral gericht op hygiënische maatregelen zoals bijvoorbeeld de aanleg van riolering en waterleiding, tegengaan van verkrotting, verbreding en verharding van straten, zorgen voor vuilophaaldiensten en steun voor armlastigen. Later kwam het accent meer te liggen op het bewaken en bevorderen van de gezondheid van de jeugd, het tegengaan van infecties, en het beschermen van water, bodem en lucht zodat onze gezondheid niet in gevaar komt. Tot 1989 voerde de landelijke overheid dit beleid uit, het ministerie van Volksgezondheid, Welzijn en Sport (VWS) in Den Haag dus, met hulp van de GGD'en - de gemeentelijke of geneeskundige gezondheidsdiensten. Vanaf 1989 werden gemeenten verantwoordelijk voor dit beleid, omdat Den Haag vond dat gemeenten veel beter de behoeften kennen van hun burgers. Gemeenten zijn daarom beter in staat lokaal passende maatregelen te nemen. De gemeenteraad, als hoogste politieke orgaan, beslist dus vandaag de dag over het gemeentelijke volksgezondheidsbeleid. GGD'en adviseren en ondersteunen bij de uitvoering ervan. 


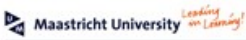

\section{GGD-regio's 2014}

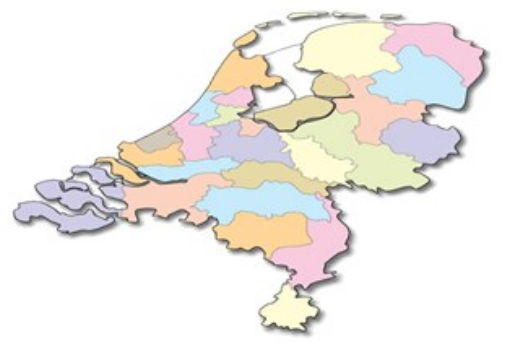

Bron: GGD-Nederland www.zorgatlas.n

Caphri Schol tor pubtec thosth

Om het voor GGD'en een beetje werkbaar te houden is landelijk afgesproken dat gemeenten in een bepaalde regio samenwerken en eenzelfde beleid uitzetten. Zo zijn er 25 GGD-regio's die samen de 393 gemeenten in Nederland bedienen (RIVM, 2015c)

Maastricht University $\cdots$

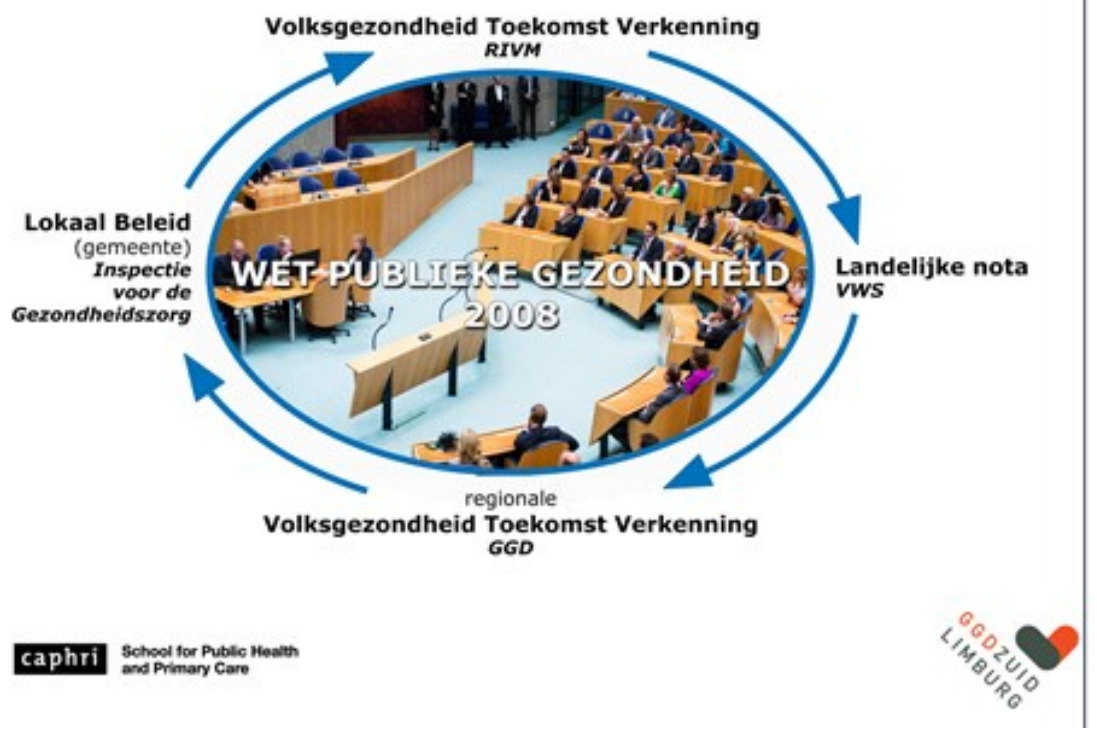

Landelijk zijn door het

ministerie van VWS wel enkele basistaken vastgelegd die elke gemeente moet uitvoeren, zoals bijvoorbeeld medische opvang van asielzoekers of veiligheid en crisismanagement ingeval van calamiteiten. Verder geeft Den Haag ook elke vier jaar aan wat de prioriteiten zijn die gemeenten moeten opvolgen. Daarnaast voert elke GGD de taken uit die door de gemeenten zijn vastgesteld (Ministerie VWS, 2013 en 2014).

Elke gemeente doet dat na de gemeenteraadsverkiezingen iedere vier jaar weer opnieuw. Dan wordt een gemeentelijke nota volksgezondheid opgesteld. Als gemeenten dit niet netjes doen dan meldt de Inspectie van de Gezondheidszorg dit aan VWS, wordt de gemeente daarop gewezen en volgt er strenger toezicht. De overheid zorgt dus voor uw gezondheid.

Wat is dan het verschil tussen wat de overheid doet en wat de huisarts of de specialist doet? Huisarts of specialist treden pas op als $u$ ziek bent of klachten heeft. Ongezondheid is voor hen het uitgangspunt. Gemeenten treden op als u nog gezond bent met de bedoeling om dat zo te houden. Volksgezondheidsbeleid is bedoeld voor de hele bevolking, we bieden het u gewoon aan, u hoeft er niet naar te vragen, iedereen kan er gebruik van maken. 


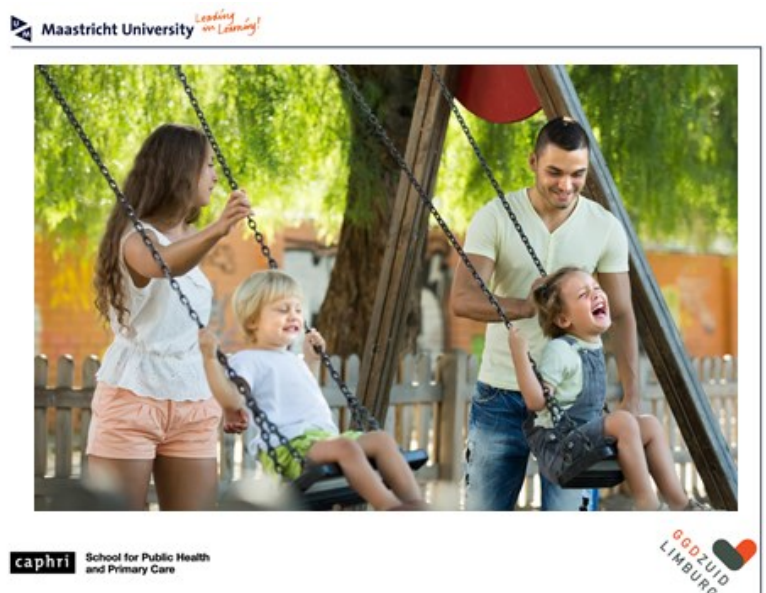

Zo leggen gemeenten bijvoorbeeld speelveldjes aan waar kinderen veilig kunnen spelen. Dat vinden kinderen leuk en het is goed voor hun lichamelijke en motorische ontwikkeling. Ouders ontmoeten elkaar hier en dat is weer goed voor de onderlinge contacten. Zo draagt een eenvoudig speelveldje bij aan het welzijn van kinderen en hun ouders. Het beleid is dus niet reactief, als reactie op een zorgvraag van een individu die ziek is of klachten heeft, maar juist proactief, om mensen gezond te houden. De meeste voorzieningen vindt u bovendien buiten de gezondheidssector, zoals Cruijff courts in de buurt of veilige fietsroutes. En wat dacht u van werkgelegenheid: arbeid is over het algemeen genomen goed voor uw gezondheid (Burdorf, 2014; Carlier et al, 2013).

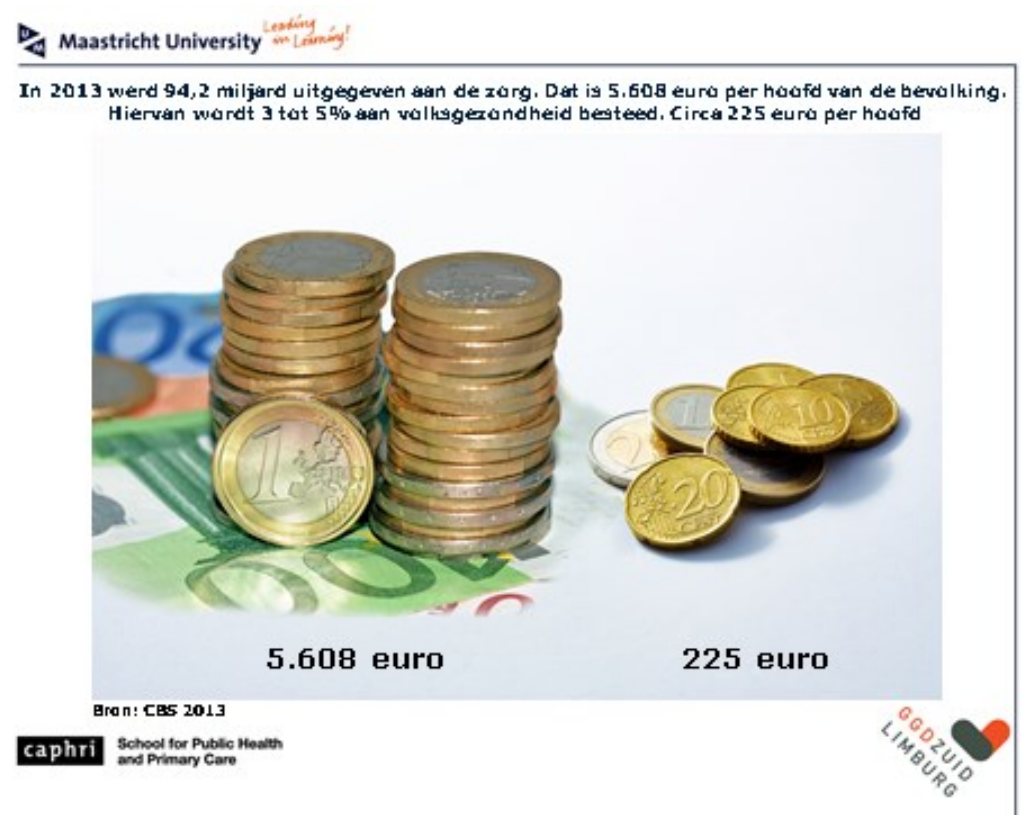

Toch wordt aan individuele zorg veel meer uitgegeven dan aan volksgezondheid. In 2013 werd ruim 94 miljard uitgegeven aan de zorg. Dat is ongeveer 5.600 euro per hoofd van de bevolking. Hiervan wordt slechts 3 tot $5 \%$ aan volksgezondheid besteed; dat is ongeveer 225,- euro per hoofd van de bevolking (CBS, 2013). 


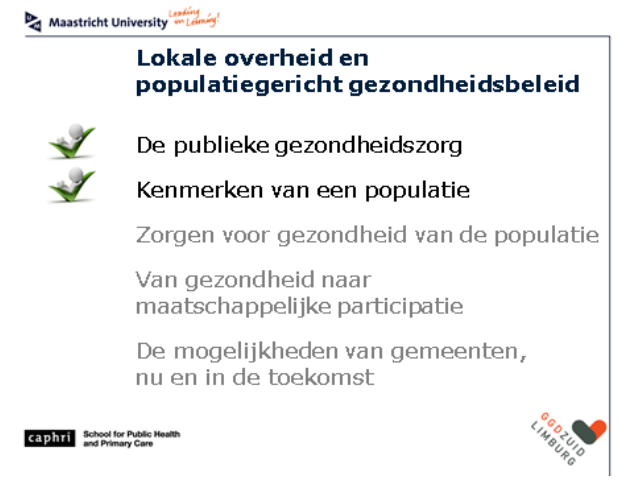

Dan wil ik nu met u ingaan op de kenmerken van een populatie.

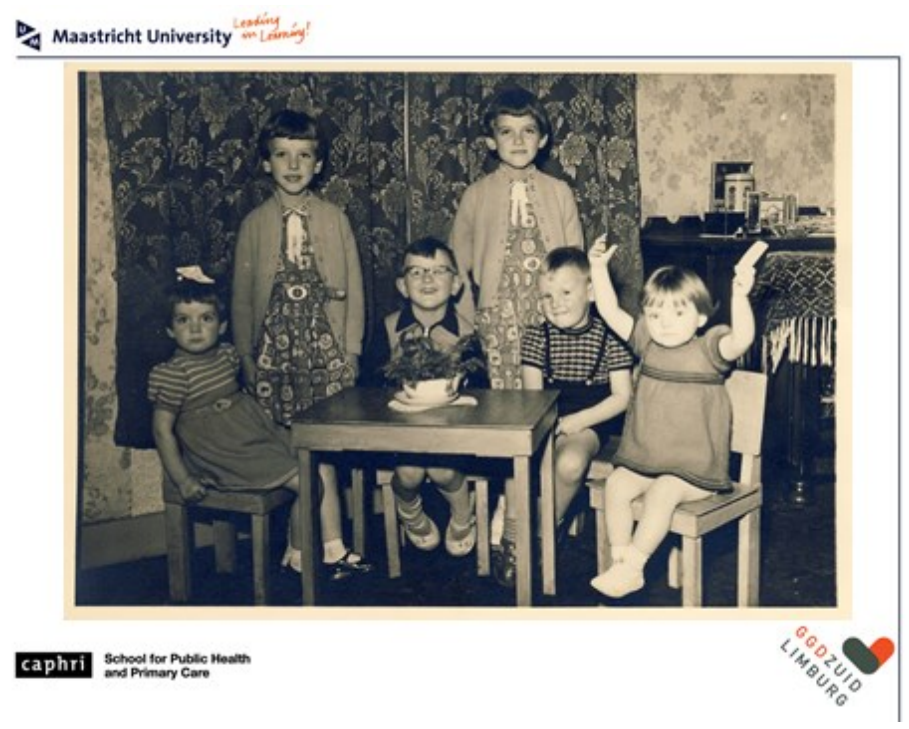

Op deze foto ziet $u$ een deel van de

familie Jansen en ik zit met het vuistje omhoog. Ik was toen de jongste. Na mij volgden er nog vijf. Een groot Rooms-Katholiek gezin. De tandarts in ons dorp noemde ons 'De Jansentjes'. Het gebruik van het verkleinwoord was ingegeven door onze tengere, ietwat frêle lichaamsbouw, maar natuurlijk ook omdat we nog klein waren, op elkaar leken, onmiskenbaar uit één gezin. Die kleine kinderkopjes uit dat grote nest leverde hem de lucratieve bezigheid op van minstens 20 periodieke tandcontroles per jaar. Bij binnenkomst in de spreekkamer verwelkomde hij ons altijd met een enthousiaste groet: "Ha daar hebben we weer een Jansentje". Dat dit nog zo levendig op mijn netvlies staat, heeft alles te maken met de zeer onaangename pijnbeleving die vrijwel altijd volgde op deze uitbundige begroeting, maar dat terzijde. De jonge Jansentjes leken dus op elkaar, we hadden kenmerken gemeen. 


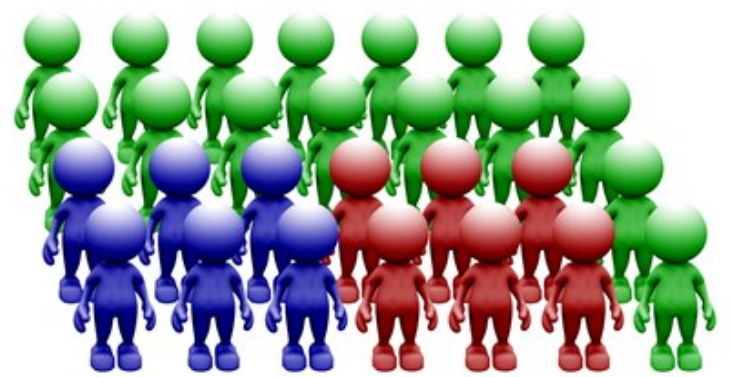

een aantal kenmerken gemeenschappelijk heeft. De populatie Jansentjes is daar een voorbeeld van, maar ook bijvoorbeeld de Maastrichtse of de Limburgse bevolking.

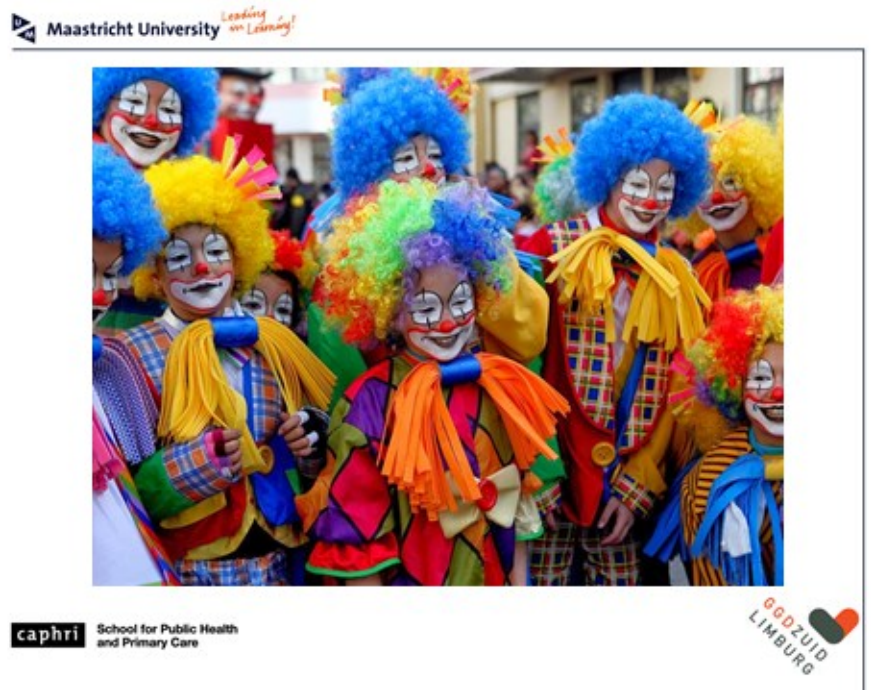

kenmerk woonplaats gemeenschappelijk en de carnavalscultuur.

De Maastrichtse bevolking heeft het

Voor een aantal nader te omschrijven kenmerken is de populatie dus een homogene verzameling van individuen. Nu zijn wij vanuit de volksgezondheid vooral geïnteresseerd in kenmerken die iets met gezondheid te maken hebben.

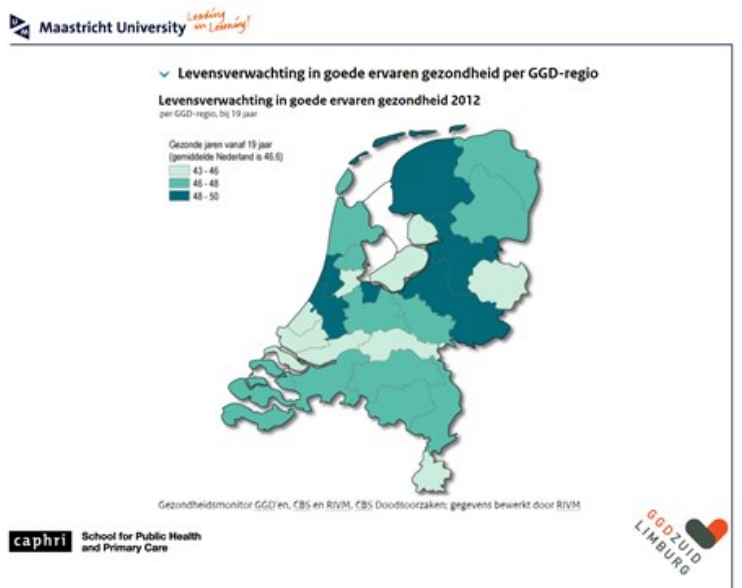

Waarom leeft bijvoorbeeld de populatie hoog opgeleiden bijna 20 jaar langer in goede ervaren gezondheid dan de populatie laag opgeleiden? Of waarom zijn er verschillen in zorggebruik tussen regio's? 
Kunnen kenmerken van populaties uit bepaalde regio's verklaren waarom Limburg verschilt van Nederland? In Nederland zegt $77 \%$ van de bevolking dat ze een goede gezondheid ervaren, in Limburg is dat $70 \%$.

De cijfers laten ook zien dat de Limburger al 10 jaar lang gemiddeld een jaar korter leeft dan de Nederlander (Steenbakkers et al, 2014). Waarom leeft de Limburger korter dan de Nederlander? Of meer algemeen: waarom leeft de ene populatie langer en in een betere ervaren gezondheid dan de andere? Welke overeenkomstige kenmerken spelen daarbij een rol? En kunnen we die boven tafel krijgen?

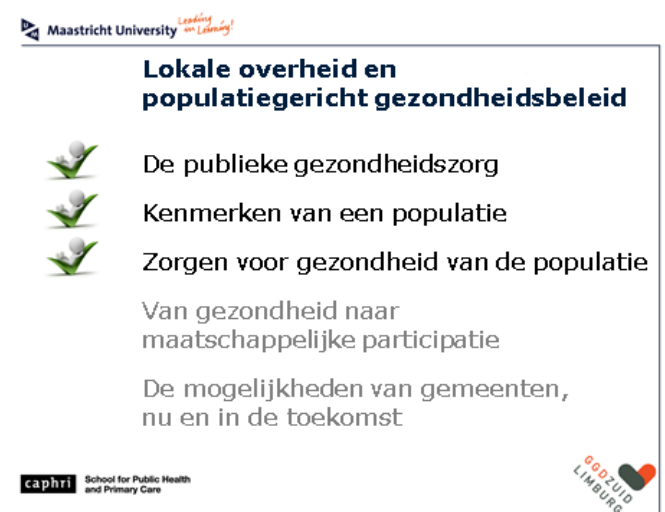

Als we dit weten kunnen we maatregelen nemen om de populatie gezond te houden, het derde punt van mijn oratie.

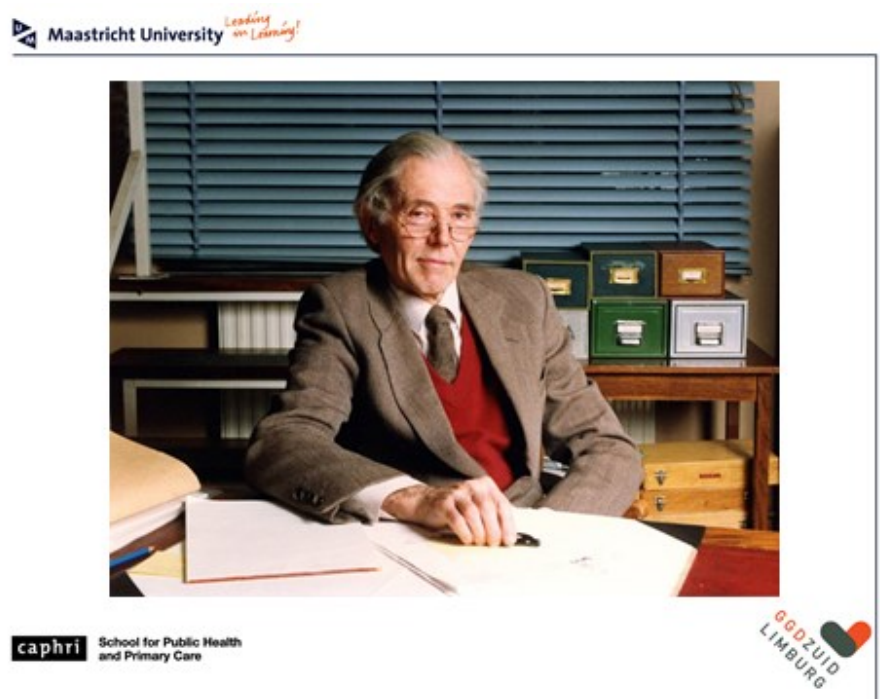

Dit brengt mij bij de theorie van Geoffrey

Rose. Als arts epidemioloog schreef hij al in 1985 zijn bekende artikel "Sick Individuals and Sick Populations" (Rose, 1985).

Hij stelde zichzelf de vraag: waarom krijgt deze patiënt deze ziekte op dit moment? Rose wilde dokters het besef meegeven dat het waarom van de ziekte minstens zo belangrijk is, want dat biedt aanknopingspunten voor preventie. En zeker als veel mensen in eenzelfde periode dezelfde ziekte krijgen. Genetische verschillen tussen zieke en gezonde populaties zijn dan te gering om het ontstaan van de ziekte te verklaren. Daarom zocht Rose naar de verschillen in de leefomgeving tussen zieke en gezonde populaties. Of tussen populaties waarin het vóórkomen van een bepaalde ziekte grote verschillen laat zien. 
Maastricht University $\cdots$ Laming!

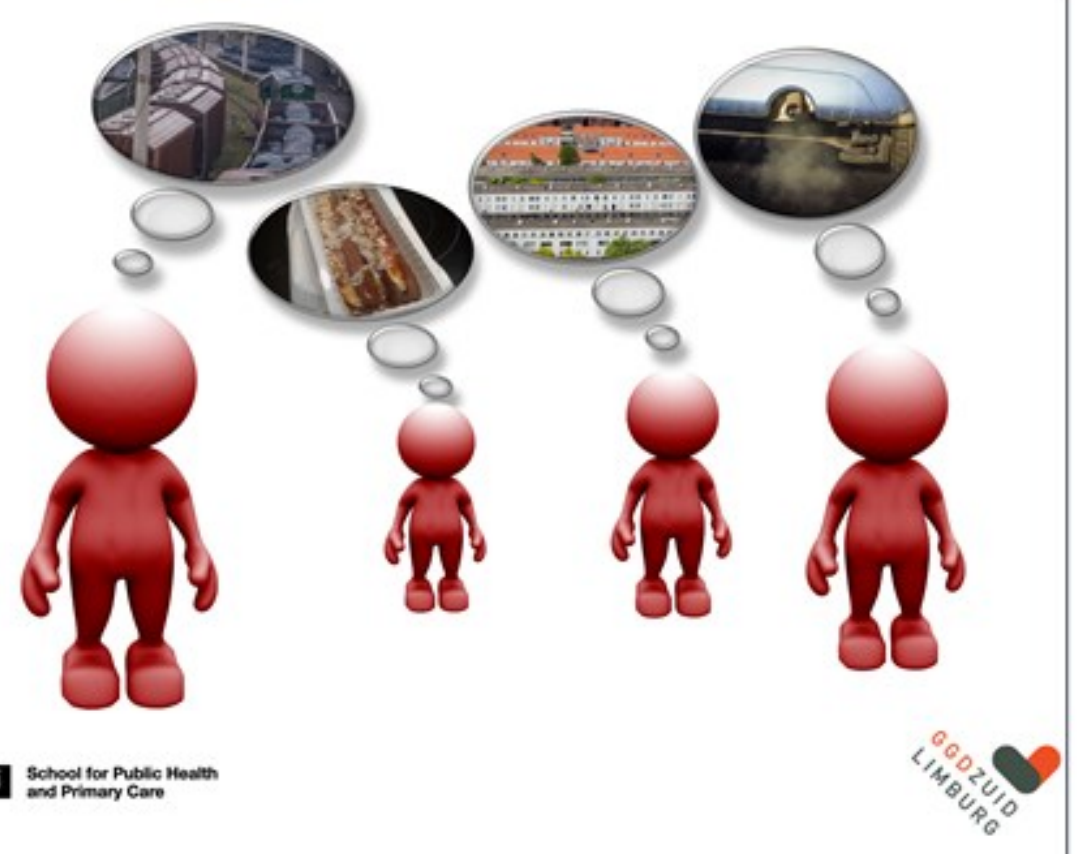

Binnen zo'n zieke

populatie is kennelijk sprake van een aantal omgevingskenmerken waardoor een grote groep op ongeveer eenzelfde moment ziek wordt.

Maastricht University $m$ Laming

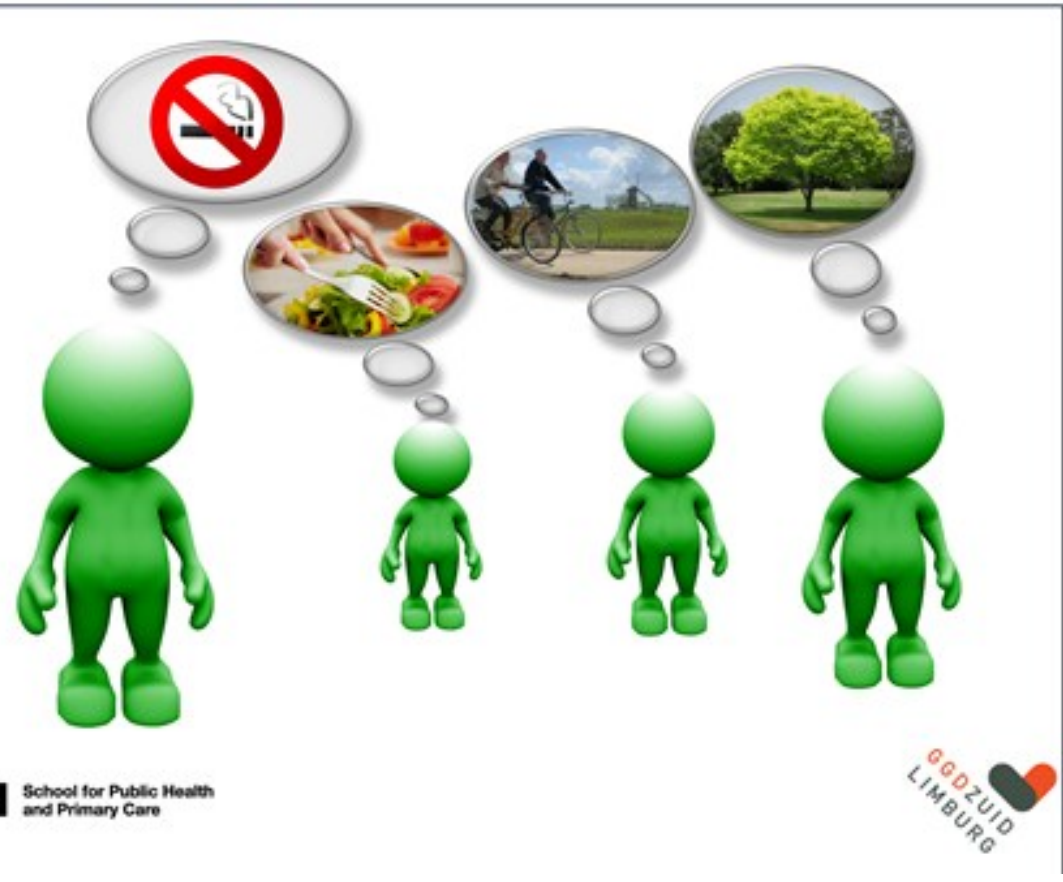

In de leefomgeving

van de gezonde populatie zien we deze omgevingskenmerken niet, of de gezonde populatie is door een aantal beschermende kenmerken niet gevoelig voor de ziekte. Als je die omgevingskenmerken voor de zieke populatie kunt blootleggen en het werkingsmechanisme erachter weet te ontrafelen, biedt dat mogelijkheden voor het voorkómen van de ziekte (Rose, 1981; Rose, 2001).

In dat geval pleitte Rose voor een populatie strategie, gericht op de omgevingskenmerken en de sociale norm. De sociale norm veranderen is bijna altijd een radicale aanpak, toch is het belangrijk omdat het voor een willekeurig individu knap lastig is om je tegen de norm in te gedragen. Vrijwel niemand doet of durft dat. Dan ben je een uitzondering en dat willen mensen niet; mensen zijn net 
kuddedieren: als iedereen rookt, rook je mee; of als iedereen met de auto zoon of dochter naar school brengt, doe jij dat als ouder ook, een enkele uitzondering daargelaten. Maar als de overheid een rookverbod instelt, een nogal radicale aanpak, verandert langzaam aan de norm. Dan beginnen minder jongeren met roken, vooral de lager opgeleide jongeren, zo laat recent onderzoek zien (Kuipers et al, 2015). Of als de schooldirectie ouders aanmoedigt te voet of met de fiets zoon of dochter af te leveren, verandert ook de sociale norm. Dan hoeft een kind zich ook niet te schamen voor ouders die het anders doen.

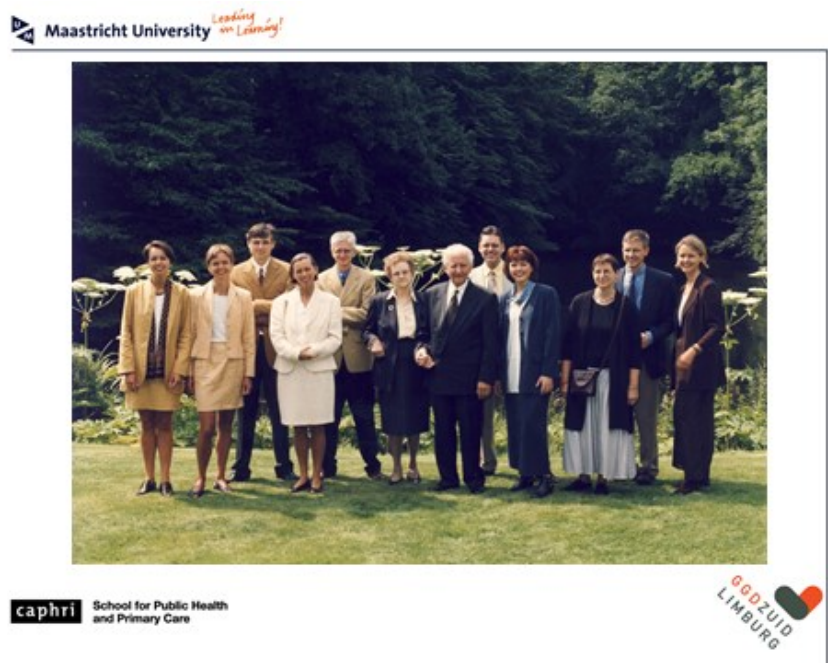

In het geval van de Jansentjes werd in die tijd tanden poetsen na het eten en voor het slapen gaan de sociale norm. Als kind wilde je bij die moderne, tandenpoetsende jeugd horen. De nieuwkomertjes in het gezin Jansen hebben daarom een veel beter gebit dan de oudsten.

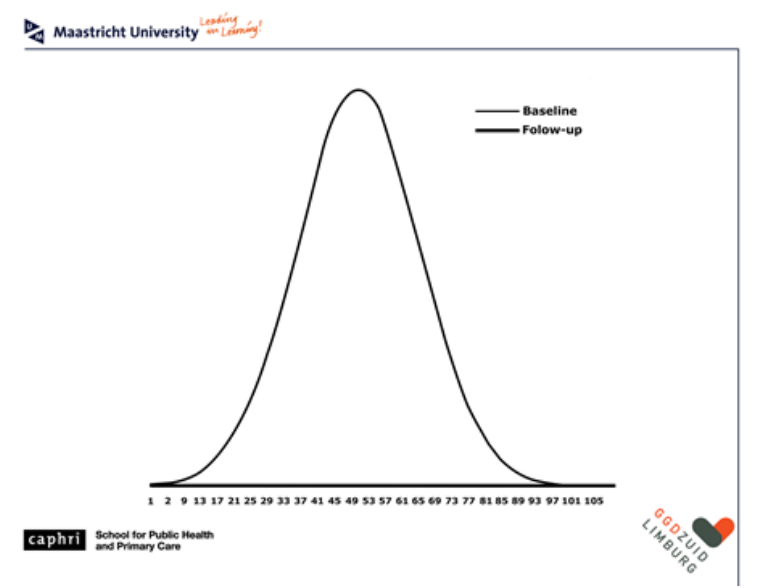

Met de populatiegerichte aanpak kun je de zogenaamde Gauss-kromme, de normaalverdeling verschuiven. Veel verschijnselen laten zich beschrijven als een normaalverdeling. Bijvoorbeeld de intelligentie van een groep van dezelfde leeftijd. De meeste mensen zitten ergens rond het gemiddelde, binnen de normale waarden, er zijn een paar uitzonderingen waarbij we vaak $5 \%$ van de groep als abnormaal beschouwen. Ook het gedrag van mensen laat zich als een normaalverdeling beschrijven. De meeste mensen zitten rond een bepaalde centrale waarde, het gemiddelde. De kans dat iemands gedrag daar van afwijkt wordt steeds onwaarschijnlijker naarmate je verder van dat gemiddelde afkomt te zitten. 


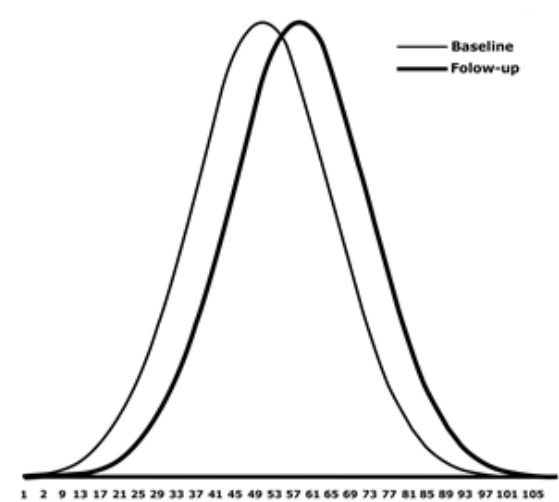

caphri

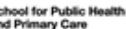

Bij een populatiegerichte aanpak verandert het populatiegemiddelde in termen van gedrag of blootstelling en de hele curve schuift mee. $\checkmark$ Mastricht University

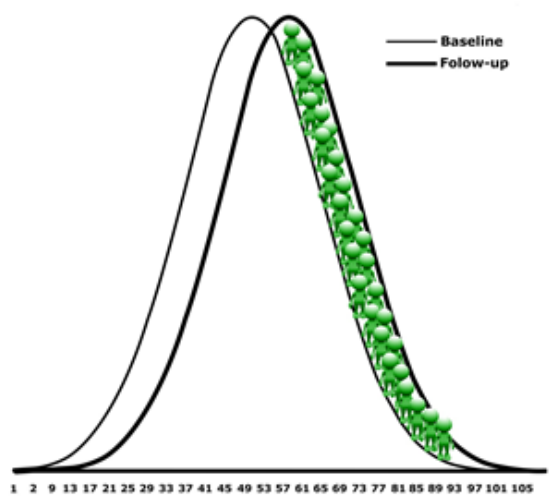

caphri Schoof for Public Hoader

Dat levert gezondheidswinst op, uitgedrukt

in het groene deel. De winst betreft een relatief kleine winst maar wel voor een hele populatie. Rose noemde dat de preventie paradox. Dat houdt in dat de groep er als geheel van profiteert, maar dat wil niet zeggen dat elk individu er dan ook persé beter van wordt (Frohlich et al, 2008). De populatieaanpak is dus een andere behandeling dan die van de arts in de behandelkamer met een individuele patiënt. Die persoon heeft al klachten of is al ziek. Hij heeft bijvoorbeeld hoge bloeddruk en krijgt daarom bètablokkers voorgeschreven door de huisarts. Dat levert dan grote gezondheidswinst op maar voor slechts één persoon. En de achterliggende oorzaak van die hoge bloeddruk wordt niet aangepakt. 


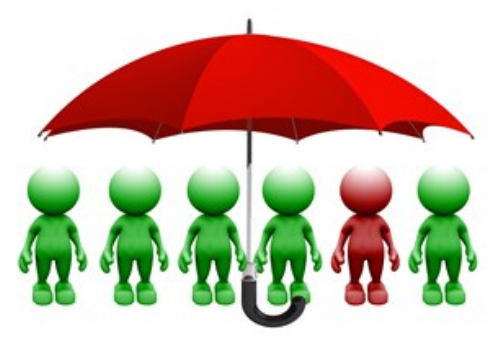

Caphril schos tor pubte Moosth

Voor sommige aandoeningen is de populatiegerichte aanpak inmiddels gemeengoed geworden, we weten bijna niet beter. Denk aan vaccinaties. We proberen alle zuigelingen te vaccineren tegen difterie, kinkhoest, tetanus, polio, de bof, mazelen en de rode hond. We weten dat je dan de hele populatie kinderen moet vaccineren om jaarlijks 50 sterfgevallen te voorkomen (Mackenbach, 2011). Als je dat niet doet, bestaat de kans op een epidemie met hoge zorgkosten en maatschappelijk leed.

Of een ander voorbeeld uit 1974-1975. Toen werden maximum snelheden op autosnelwegen ingesteld $(100 \mathrm{~km} / \mathrm{u})$ en werd het dragen van autogordels verplicht. Hier geldt hetzelfde: de hele populatie autobestuurders - enkele miljoenen dus - moet zich aan de maximumsnelheid houden en de gordel dragen. Met de verkeersintensiteit in die periode, konden jaarlijks ongeveer 400 mensenlevens worden gered (Mackenbach, 2011). Steeds geldt dat er winst is voor de populatie als geheel en dat niet elk individu er altijd voordeel van heeft, maar dat het netto resultaat positief is.

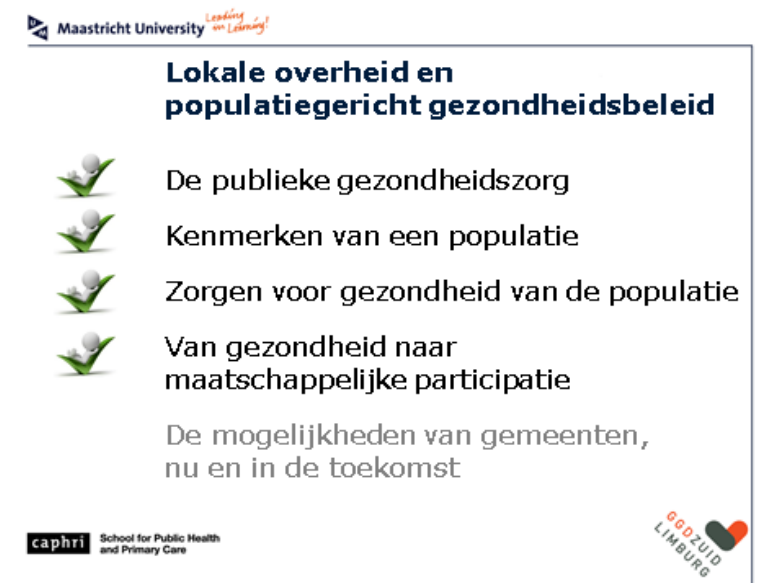

Ik zei u eerder al: gezondheid is meer dan de afwezigheid van ziekte. Het gaat erom dat u prettig kunt deelnemen aan de samenleving. Dat brengt mij op het vierde punt van mijn lezing: van gezondheid naar maatschappelijke participatie. 


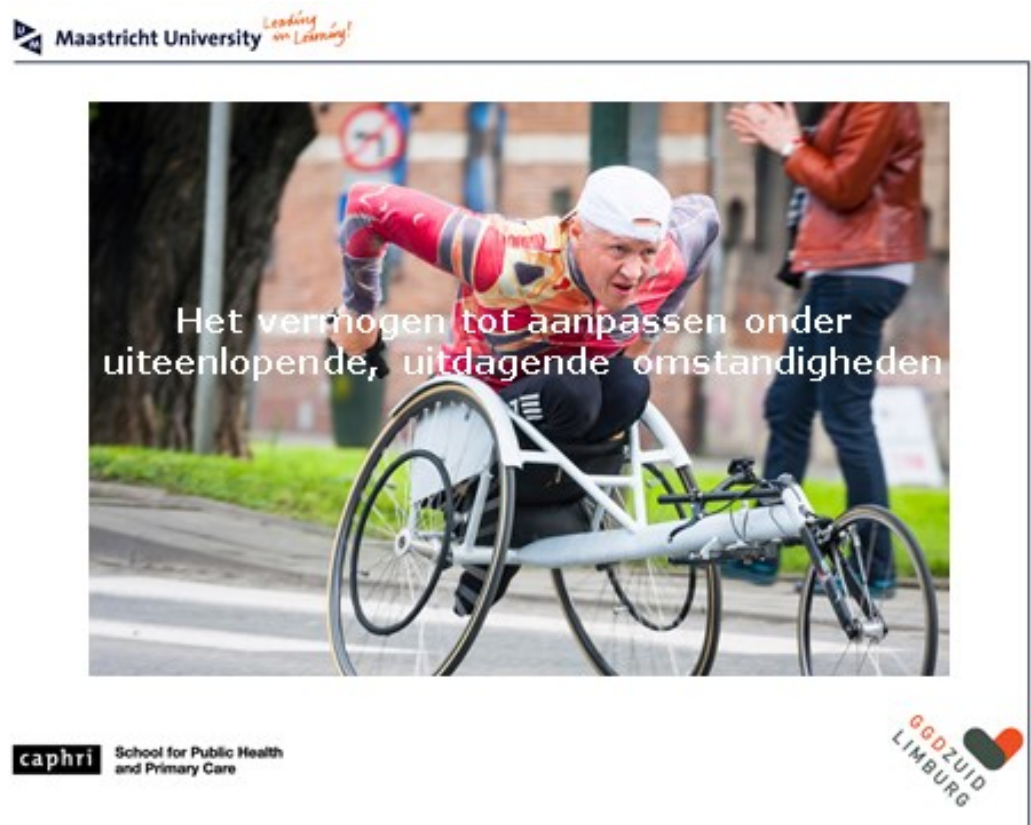

Huber en collega's hebben

een nieuwe definitie voorgesteld en die luidt: gezondheid als het vermogen tot aanpassing en zelfredzaamheid bij sociale, fysieke, en emotionele uitdagingen (Huber, 2011). Deze omschrijving doet veel meer recht aan de veerkracht, het eigen vermogen en de zelfredzaamheid van mensen. Zinvol deelnemen aan de samenleving is daarmee belangrijker geworden, dat geeft kleur en betekenis aan het leven. Maatschappelijke participatie noemen we dat in het jargon van de overheid. Dat kan door deel te nemen aan onderwijs, aan arbeid, als mantelzorger je familie ondersteunen, of door vrijwilligerswerk. Daar is de samenleving mee geholpen. De overheid ziet dat graag.

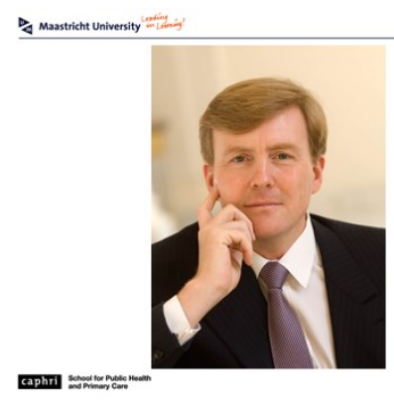

U hebt het ongetwijfeld allemaal gelezen. De Koning zei het: we gaan toe naar een participatiesamenleving. Gemeenten dragen vanaf begin dit jaar, 2015 de verantwoordelijkheid hiervoor. Gemeenten hebben al sinds 1989 de verantwoordelijkheid voor volksgezondheid en daar komt nu de jeugdzorg, de maatschappelijke ondersteuning en de arbeidsparticipatie voor mensen met een beperking bij. Om het allemaal te kunnen blijven financieren, doen de gemeenten nadrukkelijk beroep op de zelfredzaamheid van de burger. Steeds wordt de vraag gesteld: wat kunt $u$ op eigen kracht, met hulp van familie of vrienden of andere mensen uit uw omgeving. 


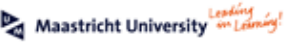

Lokale overheid en

populatiegericht gezondheidsbeleid

De publieke gezondheidszorg

Kenmerken van een populatie

Zorgen voor gezondheid van de populatie

Van gezondheid naar

maatschappelijke participatie

De mogelijkheden van gemeenten, nu en in de toekomst

Dat is een uitdagende opgave. Die

uitdaging brengt mij bij punt 5 van mijn betoog en brengt mij tegelijk weer terug bij de populatiegerichte aanpak waar Rose voor pleit. Kunnen gemeenten het overlaten aan de burgers? Om die vraag te kunnen beantwoorden heb ik samen met collega professor Hans Bosma onderzocht of er deelpopulaties zijn die zich niet zo makkelijk zelf kunnen redden.

En voordat ik nu verder ga, wil ik opmerken dat er veel meer personen bij dit onderzoek betrokken waren, maar ik noem alleen de naam van de hoofdonderzoeker of de projectleider en niet het hele begeleidingsteam. Dat doe ik ook in de volgende voorbeelden. Niet omdat deze begeleiders niet belangrijk zouden zijn, integendeel. Ik doe dat om lange opsommingen te voorkomen.

Ik heb met Hans Bosma gekeken naar de kenmerken van de populatie en we hebben ons afgevraagd: kan iedereen zichzelf in voldoende mate redden? Daarbij hebben we gebruik gemaakt van de gegevens van de gezondheidspeiling van de GGD onder bijna 12.000 Limburgse volwassenen in 2009 en bijna 25.000 in 2012. Hieruit hebben we alle mensen geselecteerd met ziekten als diabetes, hart- en vaatziekten en kanker. Dat was ongeveer veertig procent van de hele populatie (dus 4.800 respectievelijk 10.000). Vervolgens hebben we die groep op basis van inkomen in vijf groepen opgesplitst: van een heel laag tot en een heel hoog inkomen. We hebben onderzocht in hoeverre deze mensen eenzaamheid ervaren en hoeveel sociale contacten zij hebben.

Maastricht University $\cdots$ Laming

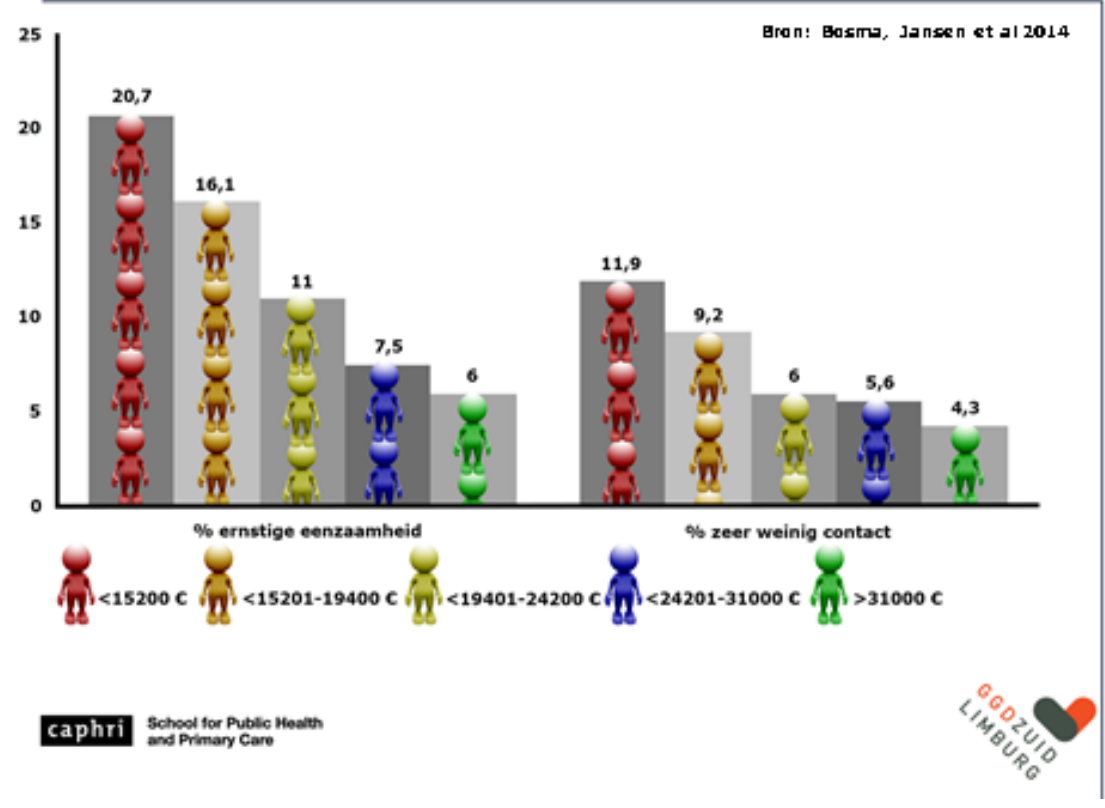

Dan blijkt dat er grote 
verschillen bestaan tussen de armste zieken en de rijkste zieken. In cijfers voor 2012, hier op de dia: bijna 21 procent van de armste zieken (de rode poppetjes) ervaart ernstige eenzaamheid tegen 6 procent van de rijkste zieken (de groene poppetjes). Bij ernstige eenzaamheid gaat het om mensen die haast niemand om zich heen hebben. Zij ervaren een grote leegheid en voelen zich vaak afgewezen. Verder geldt dat bijna 12 procent van de armste zieken (weer in rood) tegen ruim 4 procent van de rijkste zieken (weer in groen) zegt heel weinig contacten te hebben. Dat wil zeggen dat mensen minder dan twee keer per maand contact hebben met familie, buren of vrienden (Bosma et al, 2014). De cijfers van 2009 waren iets gunstiger. De situatie is in de periode 2009-2012 verslechterd. Het hogere percentage van sociale isolatie was voor een deel te verklaren door grotere werkloosheid en een hoger percentage gescheiden volwassenen. Het hogere scheidingspercentage in deze groep is symptomatisch voor de toename van steeds lossere persoonlijke verbintenissen (Shor et al, 2012; Mental Health Foundation, 2010). Wie ziek wordt verliest dan niet alleen zijn inkomen, maar vaak ook de mensen om zich heen. Zeker als het niet lukt om weer werk te vinden, brokkelt het sociale netwerk van deze mensen volledig af en raken zij vervreemd van de samenleving (Holland et al, 2011). Dat uit zich vaak ook in het stemgedrag, of in de keuze om juist niet te gaan stemmen. Mensen raken hun geloof in de politiek, de samenleving en instituties kwijt.

Wat betreft de zelfredzaamheid van de burger, schetsen onze resultaten dus een vrij somber beeld voor met name de armste zieken in onze samenleving. Gemeenten moeten er dus op letten dat het participatiebeleid dat zij opstellen, voldoende kansen biedt voor de populatie als geheel inclusief de armste zieken.

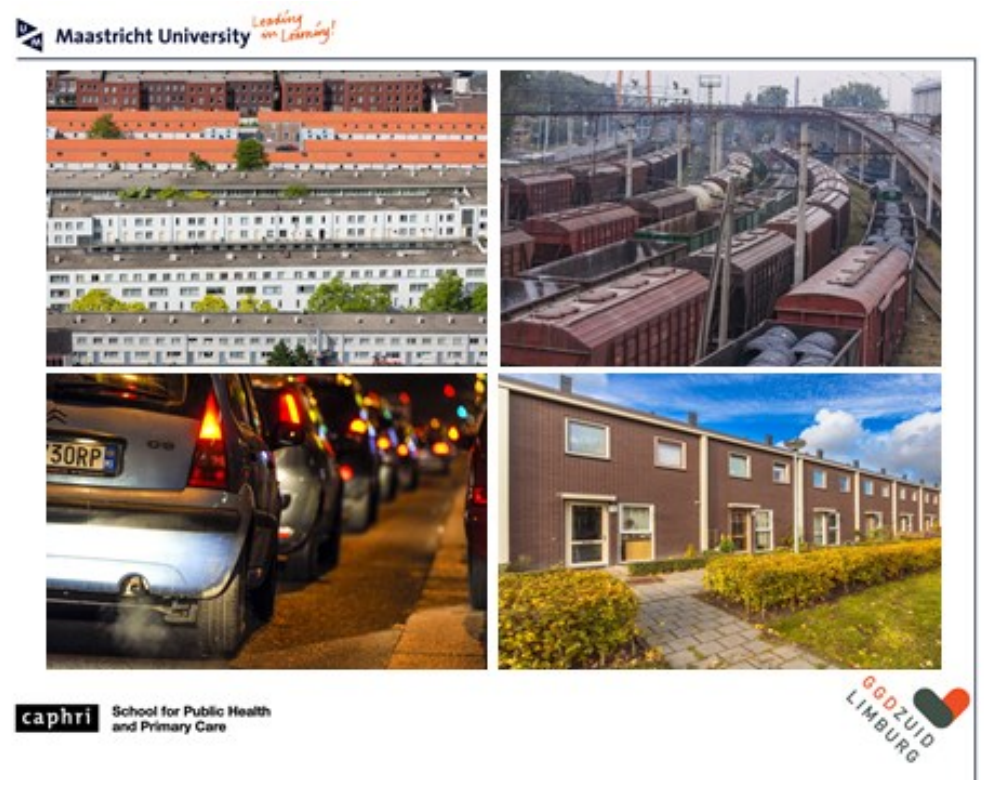

We hebben ook gekeken naar omgevingsfactoren die invloed hebben op de gezondheid van een populatie. Promovenda Polina Putrik voert dit onderzoek uit. Maastricht, Parkstad en Sittard-Geleen peilen eens in de twee of vier jaar hoe buurtbewoners hun buurt beleven als het gaat om veiligheid, verkeersdrukte, openbaar vervoer, winkelvoorzieningen, onderlinge contacten, groenvoorziening etc. Polina heeft onderzocht of de directe leefomgeving van invloed is op de kwaliteit van leven, ervaren gezondheid en depressieve klachten. In alle drie de gemeenten vond ze eenzelfde patroon.

Mensen die in onveilige buurten wonen, of in buurten met weinig onderlinge contacten, scoren slechter op ervaren gezondheid. In onveilige buurten met veel trein- en verkeerslawaai worden bovendien vaker depressieve klachten genoteerd. Dit alles uiteraard gecorrigeerd voor mogelijke verstorende variabelen zoals leeftijd, geslacht, inkomen en opleiding. Alle andere factoren zoals bijvoorbeeld winkelvoorzieningen, deden er eigenlijk niet toe voor de volwassen populatie. Wat leren we hiervan? Duidelijk is dat mensen in buurten die als minder veilig worden ervaren, met trein- en 
verkeerslawaai en weinig onderlinge contacten, zich minder gezond voelen. Ook zijn ze vaker depressief (Putrik et al, 2014).

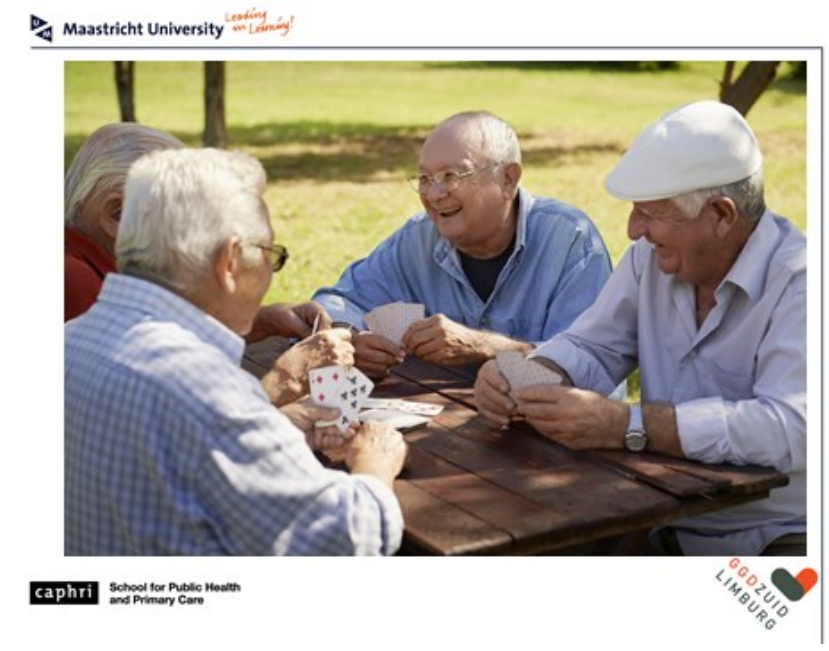

Als gemeenten gedurende langere tijd en op grote schaal trein- en verkeerslawaai kunnen terugdringen en de ervaren veiligheid en onderlinge contacten kunnen bevorderen dan draagt dit bij aan een betere mentale fitheid (Kramer et al, 2014 en 2015). De Nederlandse studie naar het nut van de Vogelaarwijken-aanpak komt tot een vergelijkbare conclusie (Droomers et al, 2014a en 2014b; Ruijsbroek et al, 2015; Vyncke et al, 2013).

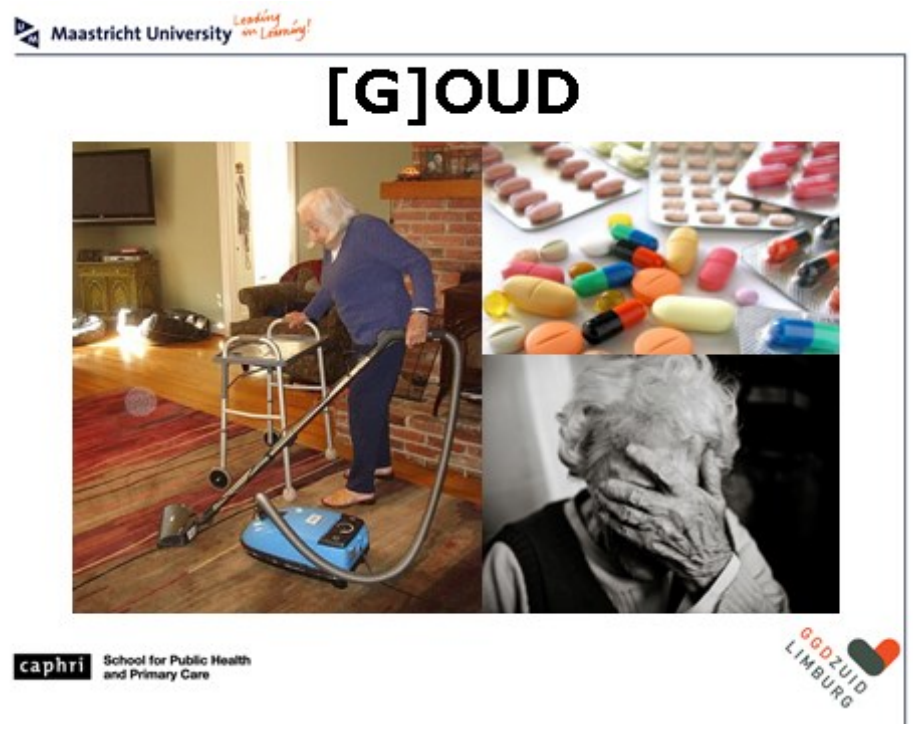

[G]OUD, Gezond Oud in Limburg is een voorbeeld gericht op de populatie 75 plussers. Mandy Stijnen is hier onlangs op gepromoveerd. Samen met de huisartspraktijken is een nieuwe, proactieve vorm van zorg ontwikkeld. Met proactief bedoel ik dat we niet wachten tot de oudere zich met een klacht bij de dokter meldt, maar dat we elk jaar, zonder dat daar direct aanleiding toe is, het welbevinden van de 75-plusser in kaart brengen. Tijdens een huisbezoek kijkt de praktijkondersteuner naar de lichamelijke conditie, mentale fitheid, sociale contacten, dagelijkse huishoudelijke activiteiten, leefstijl en het medicijngebruik. En voor de wetenschappers onder ons: dat doen we met gevalideerde meetinstrumenten. De huisarts beoordeelt de resultaten en kijkt naar de risico's. Bij eventuele risico's overlegt de praktijkondersteuner met de oudere welke verbeteropties er zijn en of de oudere dat zelf nog wil. Zo ja dan volgt een behandelplan.

Deze nieuwe werkwijze is in 13 huisartsenpraktijken uitgevoerd en vergeleken met 11 controlepraktijken waar de gebruikelijke, reactieve zorg plaatsvond. Bijna 600 ouderen boven de 75 jaar deden mee. Wat opvalt was de grote tevredenheid van de nieuwe, proactieve werkwijze bij zowel ouderen zelf als de huisartsen. Ouderen vinden het vertrouwenwekkend dat ze de huisarts goed 
kennen. De huisartsen krijgen zicht op hun ouderenpopulatie en dat vinden ze belangrijk gelet op het toenemend aantal zelfstandig wonende ouderen. Maar we vonden geen verschil in de uitkomstmaten kwaliteit van leven en zelfredzaamheid (Stijnen, 2015; Stijnen et al, 2014).

De vraag rijst: moeten we ermee doorgaan? Heeft het meerwaarde? Kan de huisarts de normaalverdeling van 75 plussers nog ietsje opschuiven naar de positieve kant? Dat zou op populatieniveau winst opleveren. Of hebben we daar naast de huisartsenzorg ook andere zorg bij nodig?

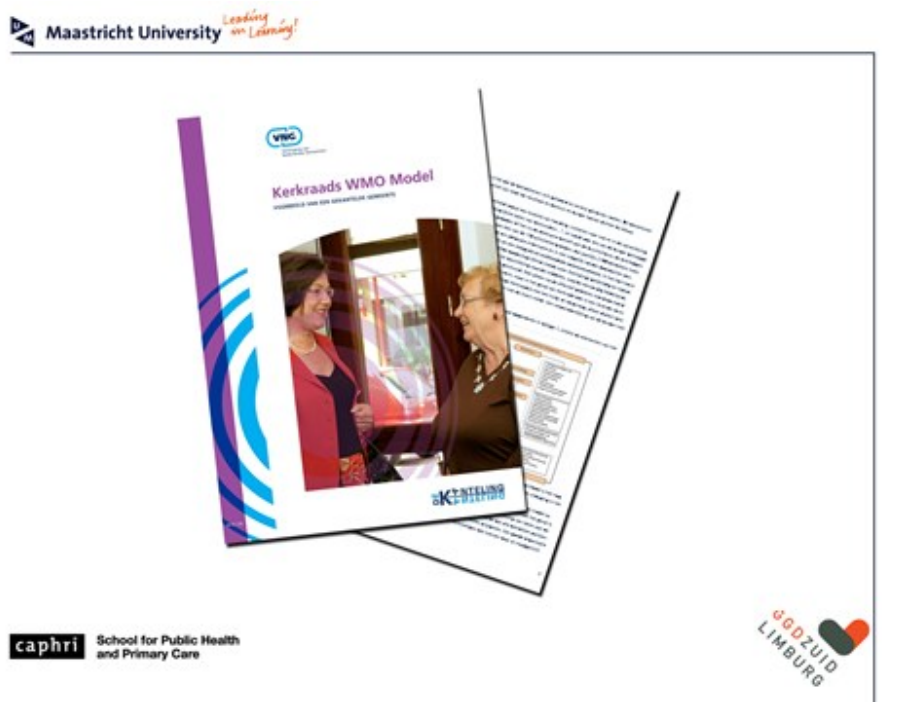

Zoals de zorg bijvoorbeeld die gemeenten bieden vanwege de Wet maatschappelijke ondersteuning. Dan kan het gaan om hulp in de huishouding of woningaanpassing, zoals beugels op het toilet of een traplift. Of het gaat om een vervoersregeling naar familie als iemand ernstig eenzaam is. Gemeenten voeren dan zogeheten keukentafelgesprekken en bespreken wat de oudere zelf nog kan of wat vrienden, buren of familie kunnen doen. Samen met gemeenten hebben we het project uitgevoerd, getiteld "Voor elkaar in Parkstad". Collega's Bert Hesdahl, Evelyne Linssen, Nathalie Janssen en promovenda Susan van Hees zijn hierbij betrokken (Janssen et al, 2015). Het gaat hier om actief burgerschap en de steun die mensen elkaar kunnen geven. Want met wat steun uit de buurt kunnen ouderen in de buurt blijven wonen.

We onderzochten ook of gemeenten en huisartspraktijken samen kunnen optrekken in de zorg voor burgers? De samenwerking van gemeenten en huisartsen zou een meerwaarde kunnen hebben. Zo leggen gemeenten het accent op de thuisomgeving en sociale contacten. Huisartsen letten op de lichamelijke en geestelijke conditie van ouderen. Zo komt de oudere als compleet mens in beeld. Karen Offermans onderzocht of meer samenwerking mogelijk is. Zij interviewde medewerkers en patiënten van zes huisartsenpraktijken in Parkstad en wethouders en beleidsmedewerkers van gemeenten. Enkele opmerkelijke bevindingen wil ik graag met u delen. 


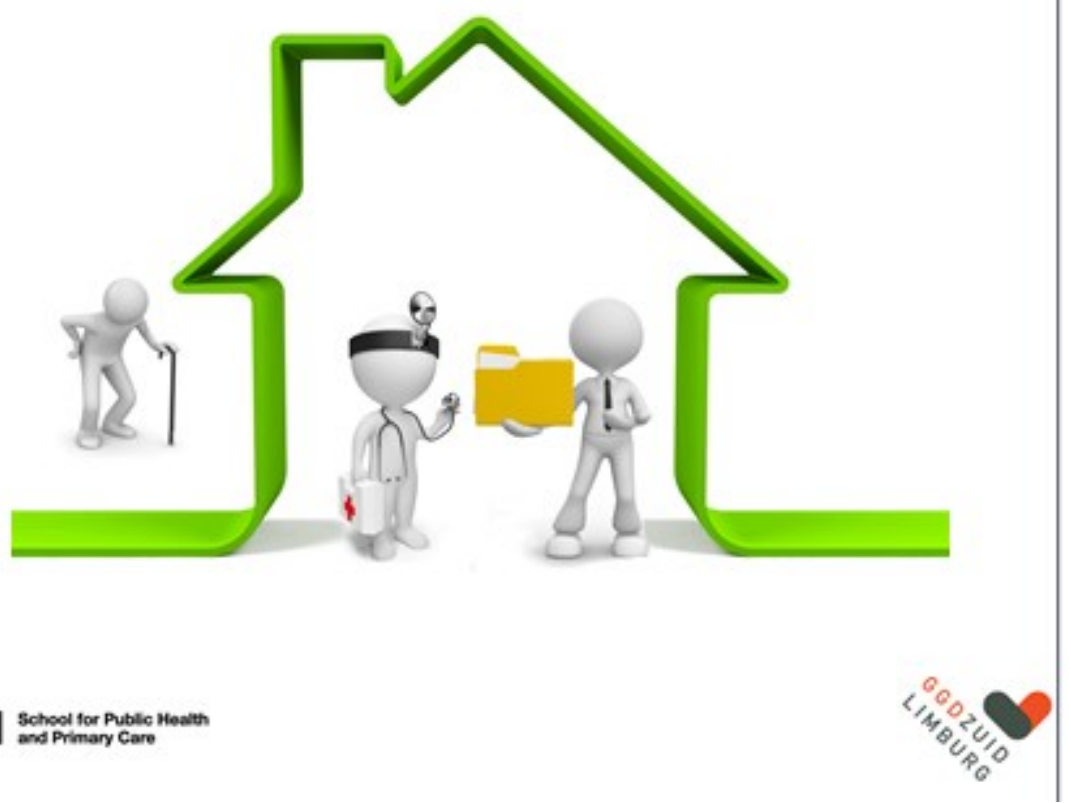

Huisartsenpraktijken

ervaren de gemeenten als star en bureaucratisch, terwijl huisartsen zelf de voorkeur geven aan een pragmatische, flexibele en concrete aanpak. Zij voelen zich geremd in de samenwerking. In de gedachtegang van veel ambtenaren zouden huisartsen meer tijd vrij moeten maken voor overleg. Overlegtijd krijgen huisartsen niet betaald. Ook bestaan wederzijds misvattingen over elkaars verantwoordelijkheden, werkwijzen en belangen. En laten we de financiële schotten in de zorg niet vergeten. Het is duidelijk dat voor deze belemmerende factoren een oplossing moet worden gevonden, want beide partijen willen graag komen tot integrale wijkzorg. Patiënten geven aan dat ze de samenwerking zouden toejuichen. De huisarts weet immers veel van hen, ook van vroeger. De Wmo consulent mag wat hen betreft gerust met de huisarts overleggen, zeker als de patiënt daar zelf vooraf mee heeft ingestemd. Zij pleiten simpel gezegd voor "alles onder 1 dak" (SchellemansOffermans et al, 2015).

Wat betreft de populatiegerichte aanpak voor ouderen maar ook voor volwassenen en jongeren in een kwetsbare positie, hebben we langzaam aan steeds meer puzzelstukjes in handen. Wat duidelijk wordt is dat de sociale en de medische zorg bij elkaar gebracht moeten worden. Misschien is het tijd voor een nieuw zorgconcept waarin huisartsenzorg, wijkverpleegkundige zorg, jeugdgezondheidszorg, sociale dienst en sociale wijkteams samenwerken zonder financiële schotten. Dat zou kunnen door bijvoorbeeld voor buurt $x$ of gemeente $y$ het budget van de gemeente en het zorgbudget van de zorgverzekeraar tijdelijk als proef in één pot te stoppen. Samen regelen zij de zorg die noodzakelijk is, volgens het principe van één gezin, één plan.

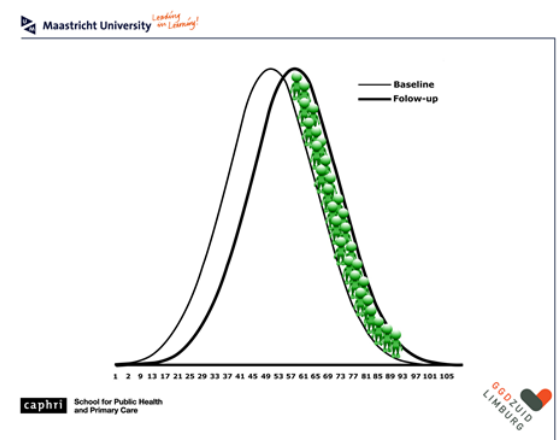

En we volgen met gedegen onderzoek of het werkt. Ook hier ligt een forse, maatschappelijke relevante uitdaging. De vraag ook hier is: wordt de populatie er als geheel beter van? 
Mastricht University ‥tingiy!

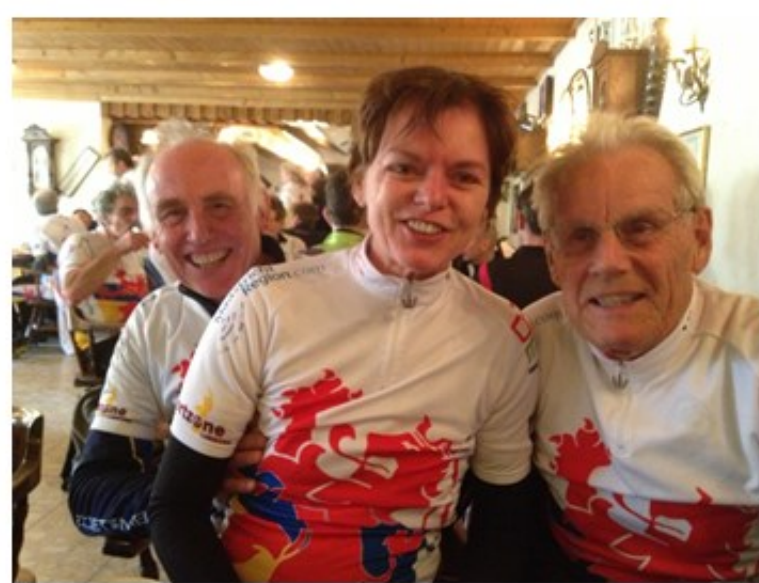

caphri

School for Puble Healty
and Primary Care

Ik fiets graag. Elk jaar fiets ik de

Amstel Gold met Jan en Joop. Kinderen spelen graag.

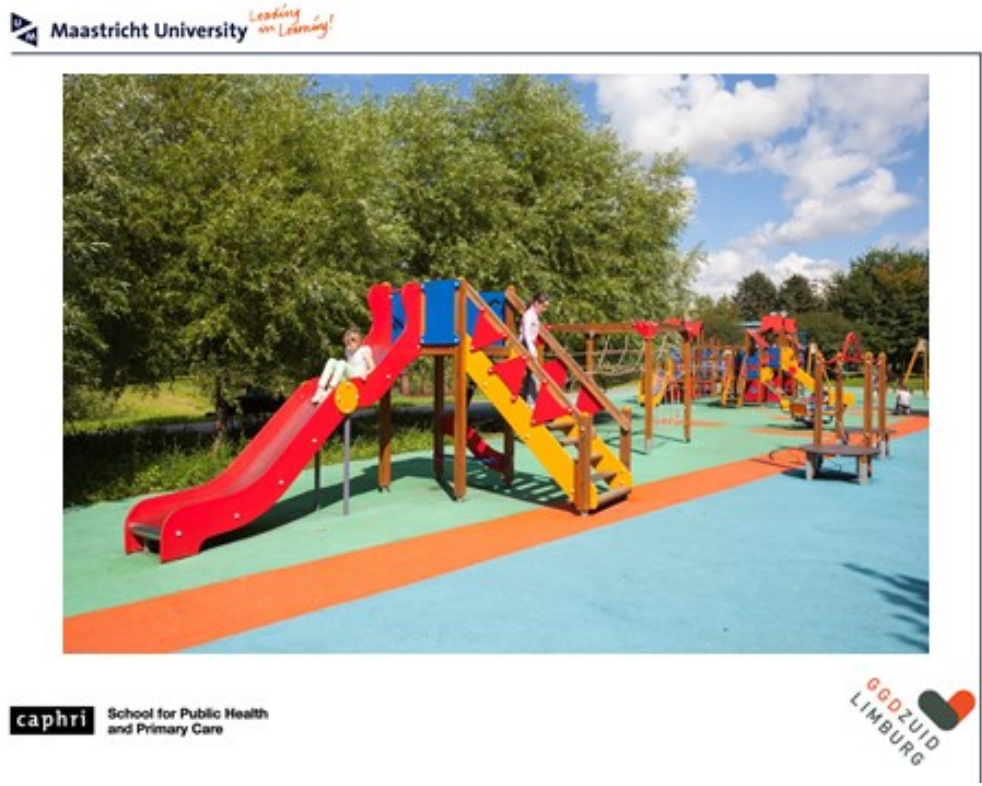

Maar worden ze voldoende

verleid? Promovendus Dave van Kann onderzoekt of de schoolpleinen van basisscholen sportiever in te richten zijn (Van Kann et al, 2014). Daarmee verleiden we kinderen om te gaan spelen.

by mastricict University

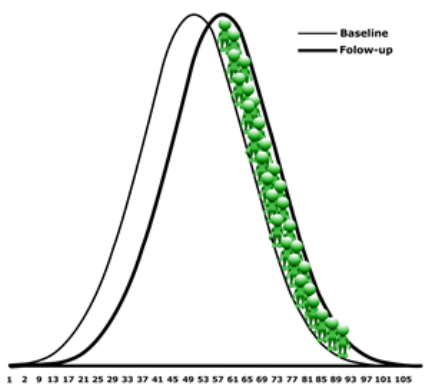

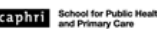

Ook hier hopen we het gemiddelde beweeggedrag van schoolkinderen in de normaalverdeling iets in de positieve richting te kunnen opschuiven. Dat geeft winst op populatieniveau. Eind dit jaar weten we of werkt. Aardige bijvangst van dit project is dat het 
pestgedrag op school is verminderd. Er zijn bijna geen ruzies meer op het schoolplein, zo zeggen leerkrachten.

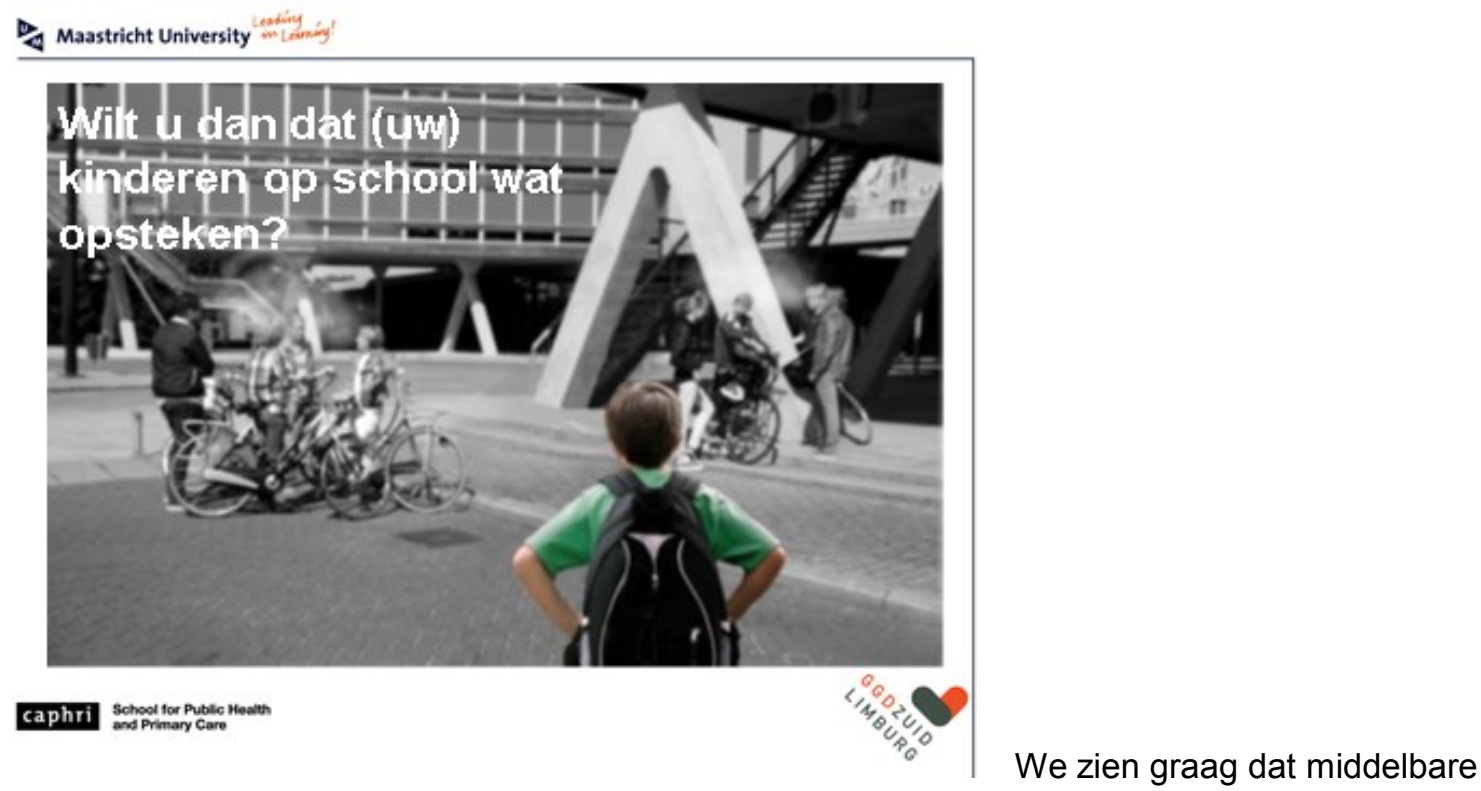

scholieren iets opsteken op school, maar geen sigaret. Promovendus Andrea Rozema onderzoekt de haalbaarheid van een rookvrij schoolterrein. De wet verbiedt wel de verkoop van tabak aan jongeren onder de 18 jaar, maar niet het roken op schoolterreinen. Nu heeft ongeveer de helft van de middelbare scholen een rookvrij schoolterrein, door de directie zo bepaald. Op de andere helft is nog gezondheidswinst te behalen.

Maastricht University $\cdots$ Laming!

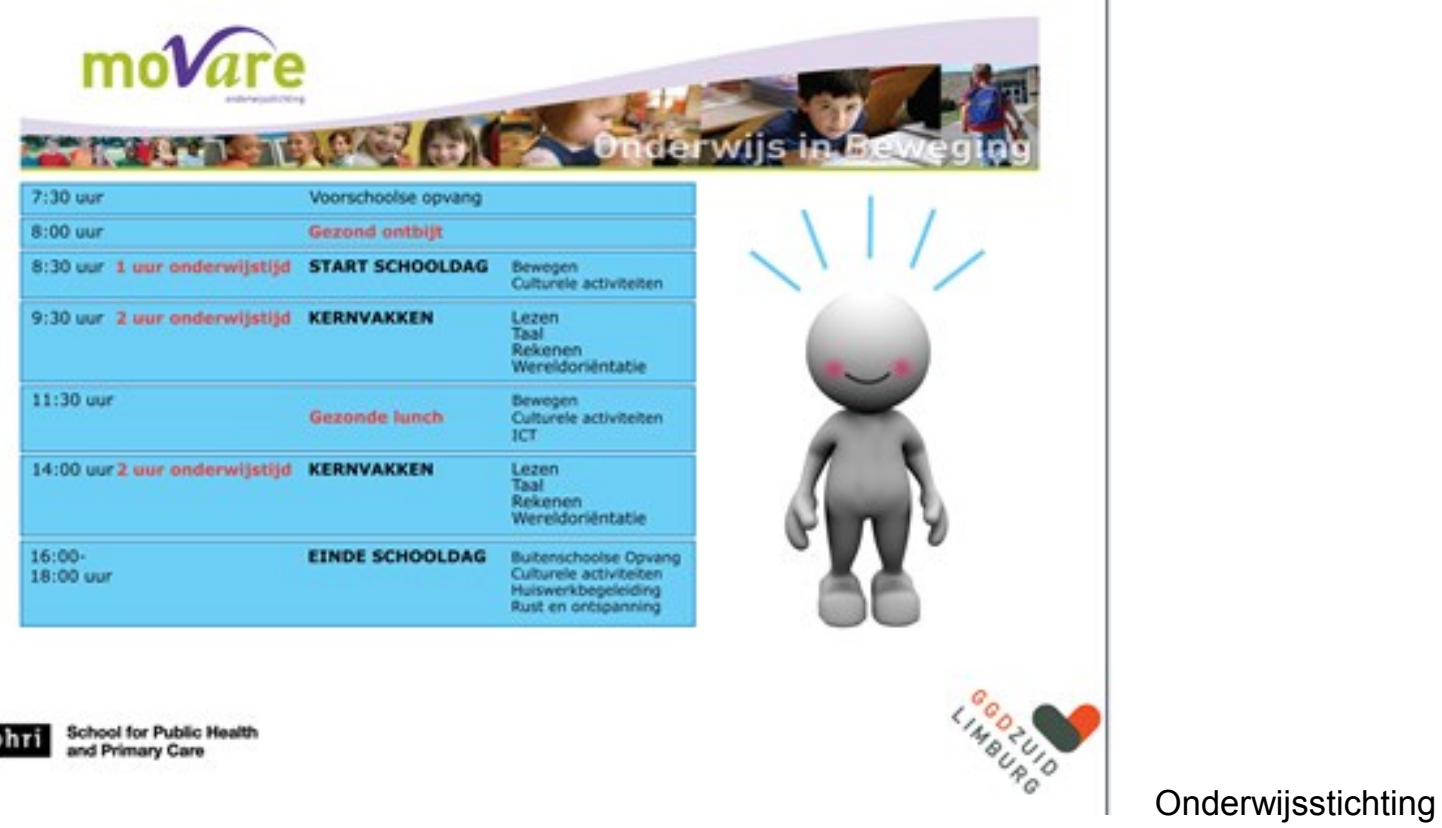

Movare, een schoolbestuur van 53 basisscholen in Parkstad, wil de schooldag anders inrichten. In de ochtend is er tijd voor spel en bewegen, daarna volgen de kernvakken lezen, taal, rekenen en wereldoriëntatie, dan een gezonde lunch, ook weer met bewegen, sport, spel en cultuur, om dan de middag te eindigen met de kernvakken. Ouders die willen kunnen gebruik maken van de voor- en buitenschoolse opvang, op school. De totale schooldag wil men 1 tot 1,5 uur langer maken, 4 dagen per week, mits ouders instemmen. Onderwijsstichting Movare hoopt te bereiken dat de leerprestaties 
van kinderen verbeteren (Schayck et al, 2013). De Provincie Limburg ondersteunt dit initiatief. Met Maartje Willeboordse en promovendi Nina Bartelink en Elise de Neubourg gaan we dit onderzoek uitvoeren in de vorm van een natuurlijk experiment. We verwachten dat verbetering van leerprestaties bijdraagt aan een betere gezondheid. Literatuur laat ons zien dat dit mogelijk is. In 2018 weten we meer.

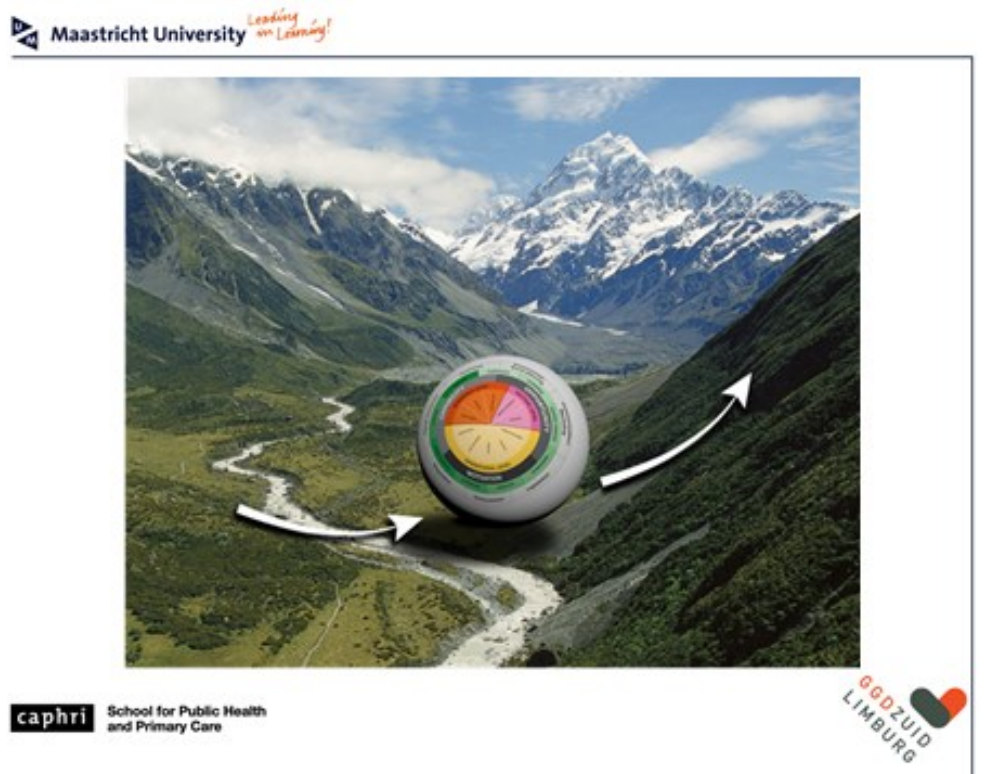

Dit laatste voorbeeld illustreert dat gezondheidsverbeteringen niet via de zorg tot stand komen maar vooral buiten de zorg. Dat zei ik u in het begin al. Maar het is niet eenvoudig om het onderwijs, de arbeidssector of de voedingsindustrie te stimuleren om iets aan gezondheid te doen. Promovenda Anna-Marie Hendriks onderzocht hoe bestuurders het thema overgewicht kunnen agenderen op andermans agenda uitgaande van hun motivatie, de kansen die zich voordoen en hun vaardigheden. Dit deed ze onder andere in de gemeente Valkenburg, samen met collega Dorien Hodiamont. Ze nam ook de dynamiek mee die zich voordoet in het politieke en beleidsmatige landschap. Ze gebruikt de metafoor van de bal in het heuvelachtige landschap. De bal moet de berg over. Soms lukt dat, dan bereikt de bal een omslagpunt en rolt ie door. Bijvoorbeeld als een gemeente geen vergunning afgeeft voor de vestiging van een fast food restaurant omdat gezondheidsargumenten zwaarder wegen dan economische argumenten (Hendriks et al, 2013).

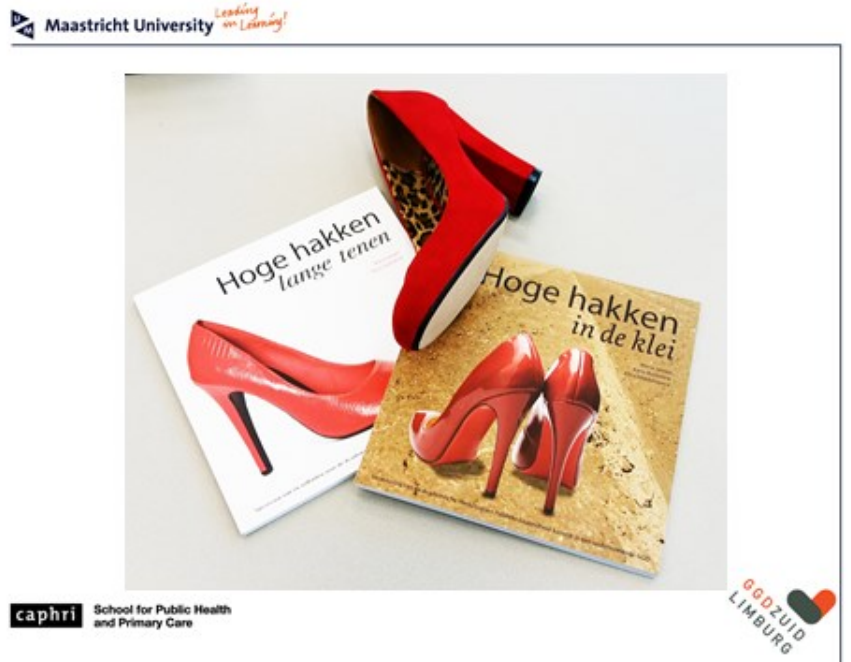

Misschien is het u opgevallen, maar onder deze toga draag ik rode hoge hakken. Schoenen van het merk Jan Jansen, geen Jansentje overigens, hij behoort niet tot de familie. De metafoor van hoge hakken heb ik vaker gebruikt. Hoge hakken zijn nodig om over de muren van de eigen instelling heen te kijken. Dan bedoel ik de muren van 
onderzoeksinstituten of die van gemeenten. Zo wordt van een onderzoeker verwacht dat hij verder kijkt dan de beschikbare wetenschappelijke kennis en dat hij dus ook gebruik maakt van de kennis die in de praktijk en bij de burger voorhanden is. Van de beleidsmaker en de praktijkprofessional wordt verwacht dat zij wetenschappelijke kennis meenemen bij het uitzetten van nieuw beleid en nieuwe werkmethoden. Als dat niet goed lukt kunnen professionals, onderzoekers en beleidsmakers samen op zoek gaan naar een betere aanpak. Kenniscoproductie noemen we dat. Dat doen we binnen de Academische Werkplaats Publieke Gezondheid (Jansen et al, 2011 en 2014).

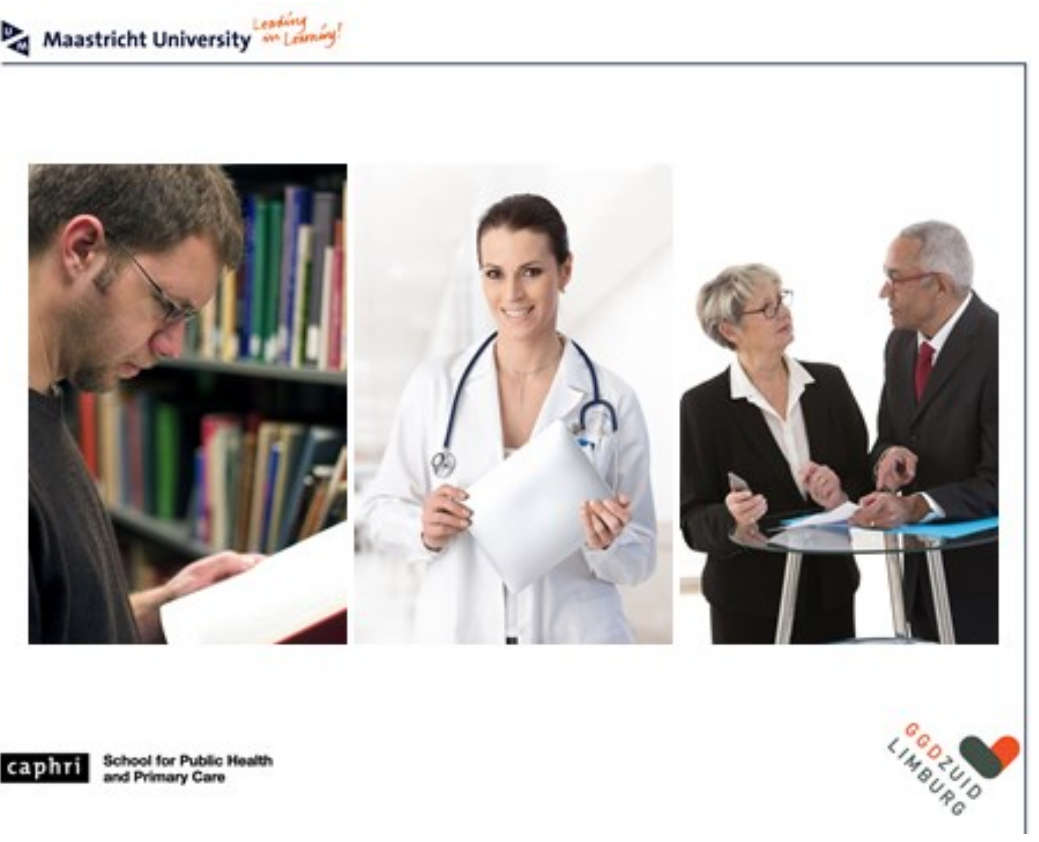

Daar werken onderzoekers,

beleidsmakers en professionals al sinds 2006 intensief samen. Die samenwerking is belangrijk. Wetenschappelijk onderzoek is nodig in de dagelijkse praktijk van de publieke gezondheidszorg, de Wmo, de jeugdzorg en de Participatiewet.

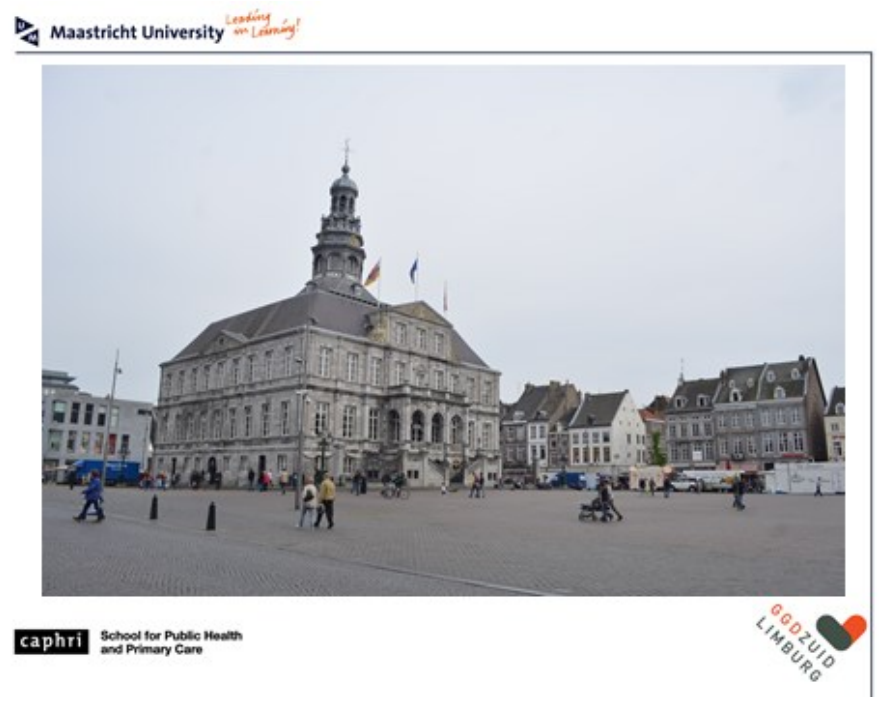

Gemeenten krijgen dan de mogelijkheid hun beleid te onderbouwen. Daarvoor verdiepen we ons in de internationale literatuur: wat is er al bekend over oorzaken en aanpak, wat zijn de effecten op populatieniveau, kunnen we die kennis gebruiken in de Nederlandse situatie? Zo ja, kunnen we het onderzoek dan zo uitvoeren dat áls die nieuwe aanpak zinvol en effectief blijkt, deze ook vol te houden is en het niet bij een eenmalig experiment blijft. We willen dus graag de noodzakelijke condities voor de uitvoering meenemen in het onderzoek. Dat is niet altijd eenvoudig. Daartoe voeren we natuurlijke experimenten uit, met observaties, interviews, en een begin en een eindmeting in proefgebieden en controlegebieden. Zo 
hopen we zichtbaar te maken hoeveel procent van de populatie er beter van wordt in termen van gezondheid of maatschappelijke participatie en welke voordelen dit oplevert voor de samenleving. Dit type onderzoek resulteert niet altijd in invloedrijke publicaties in wetenschappelijk hoogstaande tijdschriften. De universiteit wordt hierop beoordeeld. Toch is dit type onderzoek belangrijk. Samen met collega professor Dirk Ruwaard heb ik hierover gepubliceerd (Jansen, 2012). Wij vinden onderzoek in de dagelijkse praktijk van groot belang voor de samenleving omdat we daarmee de relaties blootleggen tussen de leefomgeving, de buurt, de beleidsmaatregelen en de populatie. We proberen te voorkomen dat we bepaalde zaken over het hoofd zien of essentiële zaken niet meetbaar kunnen maken. Daarom voeren we dit type onderzoek samen met het veld uit. Beleidsmakers, onderzoekers, praktijkprofessionals en liefst ook de doelgroep zelf blijven met elkaar in gesprek gedurende het hele onderzoek, en zelfs ook daarna om samen over verbeteringen na te blijven denken. Veel verbeteringen vragen immers meer tijd dan een promotietraject van 4 jaar.

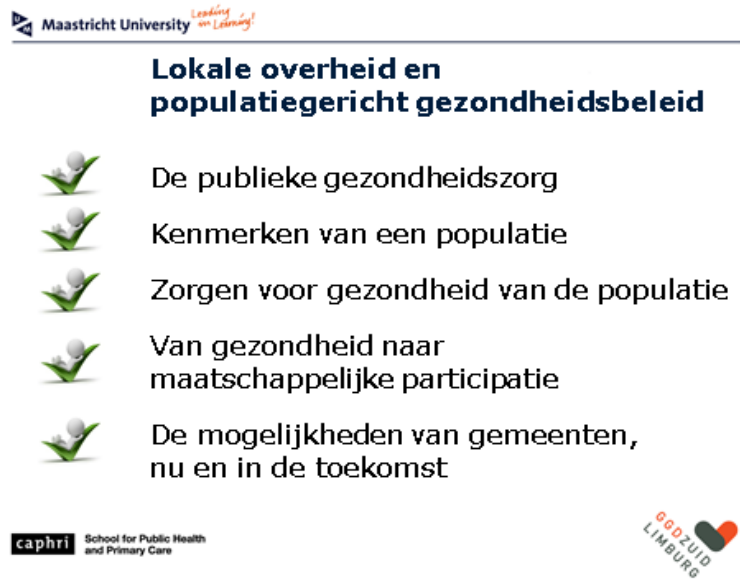

Naar de toekomst kijkend zou ik dit type onderzoek graag willen voortzetten. Ik zou daarbij ook meer gebruik willen maken van reeds beschikbare gegevens uit landelijke maar vooral ook regionale databestanden. Zo hebben gemeenten, GGD, CBS, hulpverlenende instanties, zorgverzekeraars, politie en scholen veel gegevens. Omdat deze gegevens voor andere doeleinden zijn verzameld is de wetenschappelijke kwaliteit niet altijd voldoende.

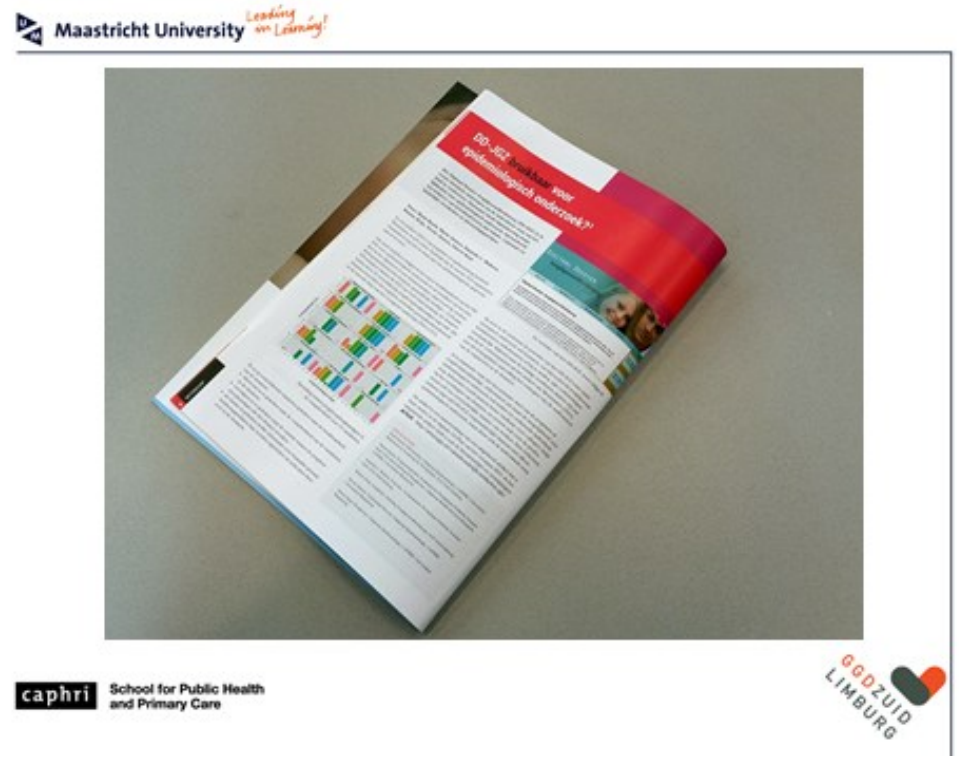

Daarom voert promovendus Huub

Hoofs momenteel een onderzoek uit naar de wetenschappelijke kwaliteit van de gegevens uit de jeugdgezondheidszorg (Hoofs, et al, 2015). Daar leren we veel van. We leren hoe we het digitaal kinddossier beter en meer uniform met collega-jeugdartsen kunnen invullen. Huub laat ook zien dat jeugdigen die anoniem vragen beantwoorden over psychosociale problemen een ernstiger beeld laten zien dan jeugdigen die dit niet-anoniem melden bij de jeugdarts. Daar moeten we rekening mee 
houden bij het beoordelen van dit soort gegevens. Ook moeten we voldoen aan de eisen van privacybescherming en integriteit als we geanonimiseerde kinddossiers hergebruiken voor wetenschappelijk onderzoek (Bouter, 2014)

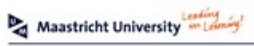

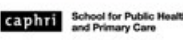

Er liggen veel nieuwe uitdagingen op het bordje van de Zuid-Limburgse gemeenten. Deze regio kampt met een tamelijke grote achterstand in gezondheid en participatie en een aanzienlijk grotere zorgvraag dan het landelijk gemiddelde. Bij de verdeling van het landelijke budget voor de Jeugdzorg, de Participatiewet en de Wmo over de 393 gemeenten wordt hier nauwelijks rekening mee gehouden. Met collega Sander van Kuijk hebben we dat doorgerekend. (Jansen et al, 2013).

Zo moeten gemeenten 15 tot $25 \%$ bezuinigen op de zorgtaken die het rijk overhevelt naar de gemeenten. Die bezuiniging in combinatie met die relatief hogere zorgvraag betekent dat dat we in deze regio slimme oplossingen moeten bedenken. Wat is het meest effectief? De lokale en regionale kennisvragen worden dus veel belangrijker. We kunnen met een populatiebril naar dit vraagstuk kijken.

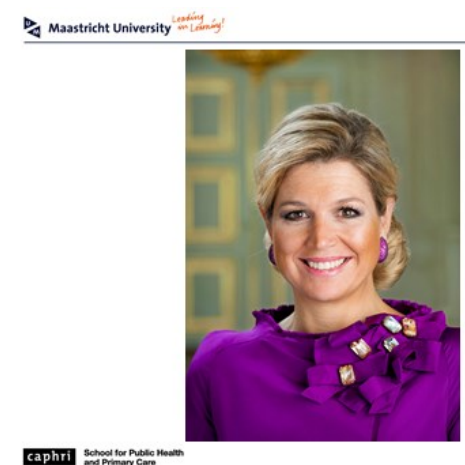

Natuurlijk kunnen we die populatie niet volledig over één kam scheren want dé Nederlander of dé Limburger bestaat niet. Zelfs Maxima zei dat.

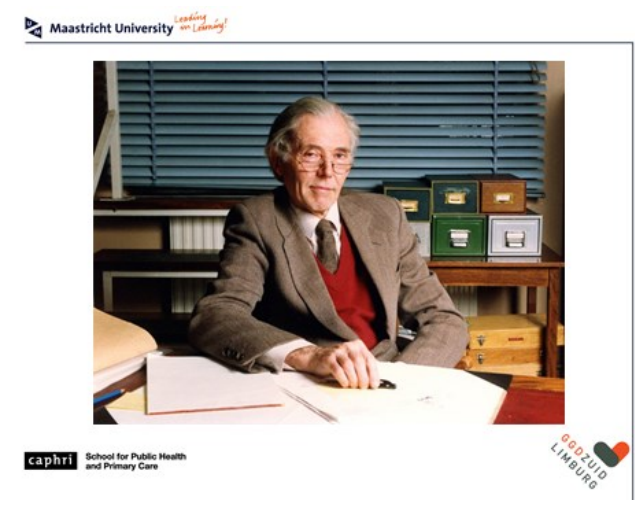

Maar als we de populatiebril van Geoffrey Rose opzetten, stellen we andere vragen. Verschilt de populatie Wmo-gebruikers van die van de niet-Wmo-gebruikers 
van dezelfde leeftijd en hetzelfde geslacht? Verschillen die populaties in zelfredzaamheid, hun leefomgeving, hun sociale netwerken en het voorzieningenniveau in hun buurt? Biedt dit aanknopingspunten voor beleid? Zijn er mogelijkheden om de normaalverdeling van enkele relevante kenmerken van de gebruikers iets op te schuiven naar die van de niet-gebruikers? En kunnen we hiermee het zorggebruik op populatieniveau terugdringen? Een populatiebril vraagt een ander blik. Gemeenten kijken tot nu toe vooral naar de zorg voor het individu. Uiteraard is het schrijnend als het daar mis gaat. Maar als bijvoorbeeld 15 van de 20 leerlingen in een klas gepest worden, is dat niet meer het probleem van de individuele leerling maar van de school. Als er relatief veel kinderen uit éénoudergezinnen in de Jeugdzorg terecht komen, is dat niet meer alleen het probleem van het individuele gezin maar ook van de samenleving. Wat kan de samenleving dan doen? Wat betreft het voorbeeld van de éénoudergezinnen (of bijstandsgezinnen) zijn er aanwijzingen dat zij baat hebben bij opvoedondersteuning als standaard basisvoorziening. Daarmee kunnen we op de langere termijn kosten in de Jeugdzorg terugdringen. Om die winst in termen van gezondheid, participatie en zorgkosten te achterhalen hebben we wetenschappelijk onderzoek nodig. Meten is weten.

Naast onderzoek zet ik mij ook graag in voor het onderwijs. Het gedachtegoed zoals ik dat aan u heb gepresenteerd, wil ik graag naar de huidige studenten en toekomstige werkers in de publieke gezondheid overdragen. Studenten leren dan naar 'heel de mens' te kijken, waarbij het vermogen tot aanpassing en zelfredzaamheid centraal staat. Studenten leren dan ook om naar de populatie als geheel te kijken om tot zinvolle preventieve maatregelen te komen. De ministeries van OCW en VWS hechten aan het bevorderen van vakkennis en bekwaamheden, zoals is opgetekend in het recent verschenen rapport over zorgberoepen (Kaljouw, 2015).

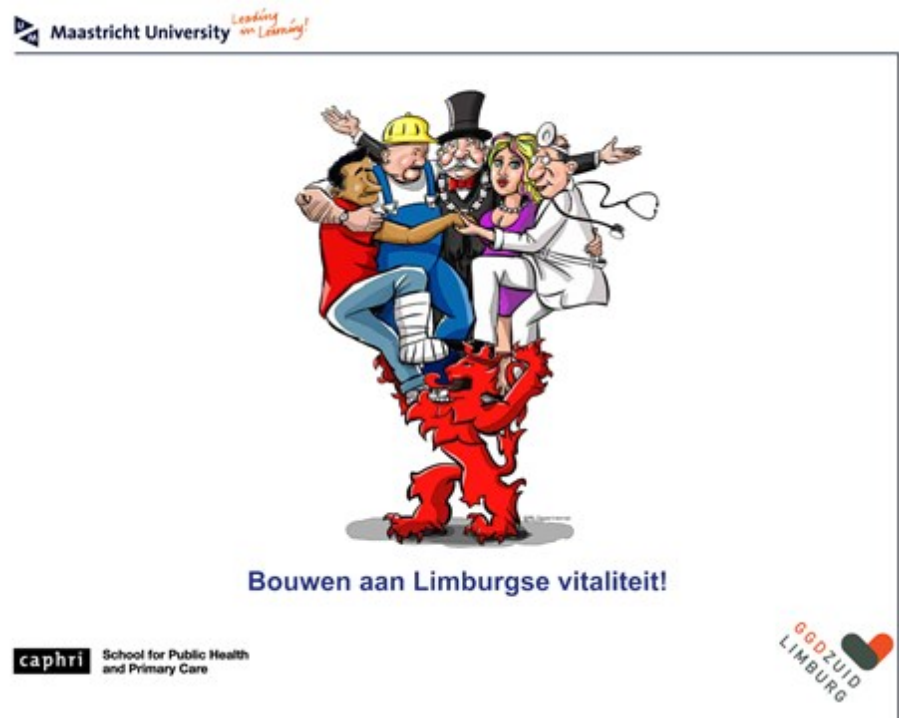

De Provincie Limburg wil de uitdagingen in de zorg en de participatie graag aangaan in, wat ze noemen, een quatro helix (Bisschops et al, 2015). Dat is een platform waarin vier partijen in een bepaalde mate van gelijkgestemdheid samenwerken. Die vier partijen zijn gemeenten, kennisinstellingen, ketenpartners en burgers. Ik nodig hen allen uit om contact met me op te nemen. Ik wil namelijk graag een bijdrage leveren aan Zuid-Limburg als proeftuin om te laten zien dat bundeling van krachten verschil kan maken in de geest van Rose.

Tot slot een woord van dank.

Allereerst wil ik het College van Bestuur van de Universiteit Maastricht danken voor het in mij gestelde vertrouwen. Ook wil ik de faculteit Health, Medicine and Life Sciences en het College van Toezicht, danken voor mijn benoeming. In het bijzonder wil ik Albert Scherpbier en Nanne de Vries danken voor hun constructieve bijdrage om deze bijzondere leerstoel mogelijk te maken. Verder wil Dirk Ruwaard heel hartelijk danken voor zijn steun. Ik ben blij dat mijn leerstoel is ingebed binnen de vakgroep 
Health Services Research om zo ook het onderzoek naar public health services structureel te versterken. Ik dank Dirk ook voor de prettige samenwerking. Jij doet wat je zegt en je zegt wat je doet, je bent inhoudelijk betrokken, eerlijk, helder en betrouwbaar. Daar kan ik mee vooruit. Het Algemeen Bestuur van de GGD en in het bijzonder de voorzitter Bas van den Tillaar dank ik voor het instellen van deze leerstoel. De GGD directie, Fons Bovens en Frank Klaassen, wil ik hartelijk bedanken voor de ruimte die jullie me hebben gegeven om onderzoek te verknopen met de praktijkuitvoering. Fons, jij bent de belangrijkste steunpilaar geweest voor mijn benoeming. Als jij er niet was geweest, dan weet ik het nog zo net niet of dit gelukt zou zijn.

Het allerleukste in mijn werk vind ik de samenwerking met mijn promovendi Anna-Marie, Andrea, Dave, Eveliene, Huub, Mandy, Mieke, Judith, Nina, Polina, Susan en Elise. Jong, leergierig, enthousiast, volhardend, creatief en ijverig. Geen 9 tot 5 mentaliteit. Jullie houden me jong en weten me altijd wel te boeien. Dank jullie wel.

In Wageningen, waar ik in de jaren 70 van de vorige eeuw aan de Landbouw Universiteit studeerde, ben ik door de colleges van Ferd Sturmans geïnspireerd geraakt voor het vakgebied van de public health. Ferd, je gaf op een aanstekelijke en gepassioneerde manier onderwijs. Daar heb ik veel voordeel van gehad. Dank daarvoor. Toen ik begin jaren 90 bij de GGD ging werken was Jan Meijers mijn grote inspirator. Jan heeft me geleerd mijn eigen koers te bepalen. Hij bood daartoe de ruimte en het vertrouwen. Fouten maken mocht want daar leer je het meeste van. Helaas is Jan veel te vroeg van ons heen gegaan.

Graag wil ik alle mensen danken met wie ik de afgelopen 30 jaar heb samengewerkt. Dat zijn er teveel om op te sommen, dus dat ga ik niet doen. Velen van jullie zitten in de zaal. Daarom veel dank aan de zaal, want mijn leven heeft kleur en glans gekregen door de prettige samenwerking met jullie allemaal.

Ik dank mijn vader en mijn moeder voor wat zij mij hebben meegegeven; een flinke dosis geluk. Ik heb voor vandaag 2 teksten voorbereid. Eén met "mijn lieve moeder kan er helaas niet bijzijn". Maar lieve moeder je bent er! Wat geweldig dat je er vandaag toch nog bij kunt zijn. Negentig jaar, dapper als altijd. Drie weken geleden zei je nog dat het te vermoeiend zou zijn en dat je niet zou komen. Als Pa hier vandaag nog bij had kunnen zijn, zou hij net als jij enorm trots op me zijn geweest. Net zoals jullie trots zijn op alle 10 de Jansentjes die allemaal iets moois van hun leven hebben gemaakt. Lieve broers en zussen, en alle aanhang, ook jullie wil ik bedanken voor de gezelligheid en de gehechtheid die wij met elkaar delen. Lief en leed delen we en ik prijs me gelukkig met zo'n warm nestgevoel. Ook mijn schoonfamilie wil ik danken, vooral ook schoonvader voor zijn warme betrokkenheid bij ons gezin.

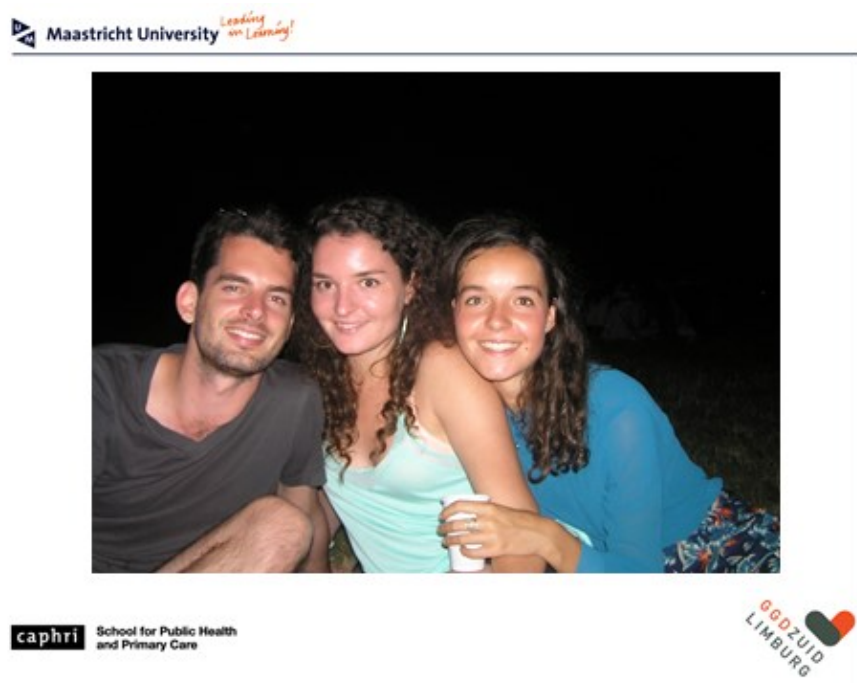

Dan Wouter, Désirée, Sophie wat ben ik trots op jullie! Daar zijn echt geen woorden voor. Jullie grijpen alle kansen aan die zich voordoen om jezelf te ontwikkelen, om verder te groeien als mens, als medeburger van Nederland, van Europa en 
zelfs als wereldburger. Geweldig om te zien hoe jullie je ook maatschappelijk betrokken voelen. Jullie zijn mijn levensmaatjes. Ik voel mij bijzonder rijk met jullie!

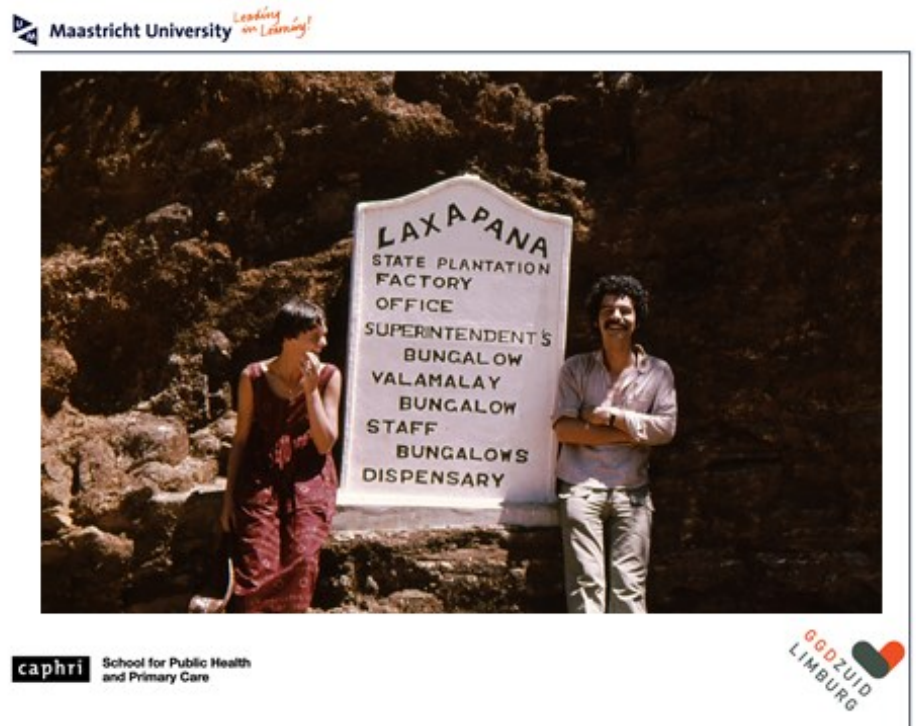

Tot slot, mijn lieve Martien. Spits je oren want ik zal het kort houden. Het aller aller gelukkigste in mijn leven is dat ik je ooit, min of meer bij toeval, ben tegengekomen. Dat vond ik toen,

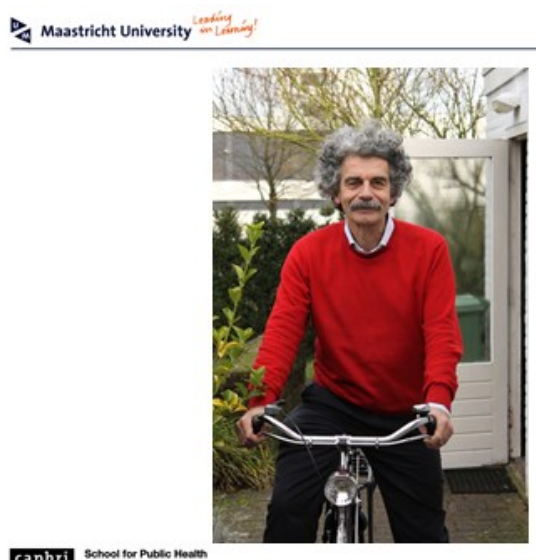

Caphri school tor Puble Hosetr

dat vind ik nog steeds

Maastricht University …taming

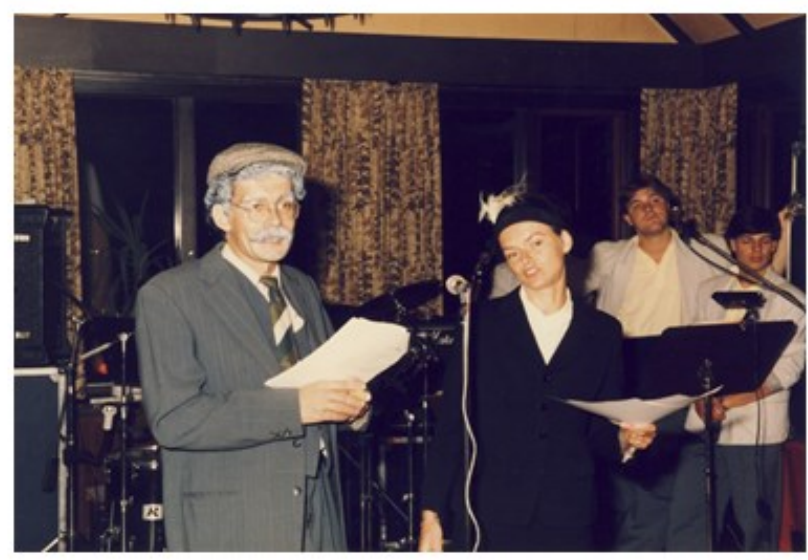


Ik heb gezegd ${ }^{a}$

${ }^{a}$ Ik dank Dirk Ruwaard en Fons Bovens voor hun opmerkingen en suggesties bij het concept van deze tekst. Daarnaast dank ik Science Vision voor de creatieve ondersteuning bij het maken van de dia's en dank ik Kyra Ubaghs en Natacha Gelissen voor de praktische hulp. 


\section{Referenties}

$\checkmark$ Bisschops L, Kuiper W, Rutten W. Bouwen aan Limburgse vitaliteit! Op weg naar een energieke quatro helix. Limburg 24 maart 2015

$\checkmark$ Bosma H, Jansen M, Schefman S, KlaasJan Hajema, Feron F. Lonely at the bottom: a crosssectional study on being ill, poor, and lonely. Public Health 2015;(129):185-187

$\checkmark$ Bouter LM. Perverse prikkels of rotte appels. Inaugurele rede Vrije Universiteit, Amsterdam 2014

$\checkmark$ Burdorf. Rotterdam Lezing 2014 Lang leven in Rotterdam. http://www.eur.nl/sgerasmus/programma gemist/chronologisch/lex burdorf rotterdam lezing/ (laatst gecheckt 21 april 2015)

$\checkmark$ Carlier BE, Schuring M, Lötters FJB, Bakker B, Borgers N, Burdorf A. The influence of reemployment on quality of life and self-rated health, a longitudinal study among unemployed persons in the Netherlands. BMC Public Health 2013;13:503 http://www.biomedcentral.com/1471-2458/13/503

$\checkmark \quad$ CBS. Gezondheid en zorg in cijfers 2013. Centraal Bureau voor de Statistiek, Den Haag/Heerlen, 2013

$\checkmark \quad$ CBS. http://www.cbs.nl/nl-NL/menu/themas/gezondheidwelzijn/publicaties/artikelen/archief/2014/2014-031-pb.htm Centraal Bureau voor de Statistiek, Den Haag/Heerlen, 2015 (laatst gecheckt 15 mrt 2015)

$\checkmark$ Droomers M, Harting J, Jongeneel-Grimen B, Rutten L, van Kats J, Stronks K. Area-based interventions to ameliorate deprived Dutch neighborhoods in practice: Does the Dutch District Approach address the social determinants of health to such an extent that future health impacts may be expected? Preventive Medicine 2014a;61:122-127

$\checkmark$ Droomers M, Kunst A, Ruijsbroek A, van Oers JAM, Stronks K. Werkt integraal wijkgericht gezondheidsbeleid? Een onderzoeksagenda. Tijdschrift voor gezondheidswetenschappen 2014b:92(5):171-173

$\checkmark \quad$ Frohlich KL, Potvin L. The Inequality Paradox: The Population Approach and Vulnerable Populations. American Journal of Public Health 2008:98(2):216-221

$\checkmark$ Hendriks AM, Habraken J, Jansen MWJ, Gubbels JS, De Vries NK, Van Oers JAM, Michie S, Atkins L, Kremers SPJ. Are we there yet?' Operationalizing the concept of Integrated Public Health Policies. Health Policy, 2013 http://dx.doi.org/10.1016/j.healthpol.2013.10.004

$\checkmark$ Hoofs H, Jansen M, Mohren DC, Reijs R, Jansen N, Kant IJ. Is het DD-JGZ bruikbaar voor epidemiologisch onderzoek? JA! vakblad van Artsen Jeugdgezondheidszorg Nederland 2015;1:10

$\checkmark$ Huber M, Knottnerus JA, Green L, et al. How should we define health? British Medical Journal 2011;343 (4163):235-237

$\checkmark$ Holland P, Burström B, Whitehead M, Diderichsen F, Dahl E, Barr B, Nylén L, Chen WH, Thielen K, van der Wel KA, Clayton S, Uppal S. How do macro-level contexts and policies affect the employment chances of chronically ill and disabled people? Part I: The impact of recession and de-industrialization. International Journal of Health Services, 2011;41(3):395413

$\checkmark$ Jansen M, Burhenne K. Hoge hakken, lange tenen. Successen van en valkuilen voor de academische werkplaatsen publieke gezondheid in Nederland. GGD-Zuid Limburg 2011. Caris \& Sak ISBN: 978-90-815704-2-8

$\checkmark$ Jansen MWJ, Ruwaard D. Making an impact instead of 'Publish or perish'. European Journal of Public Health 2012;22(5):613-614. doi:10.1093/eurpub/cks023

$\checkmark$ Jansen M, Ruwaard D, Horstman K, Kant IJ, Jungbluth P, Rutten W, Bosma H. Waarom de drie decentralisaties in het sociale domein slecht uitpakken voor Limburg. Wij maken ons grote zorgen! Academische Werkplaats Publieke Gezondheid Limburg / Kennisnetwerk Limburg. Maastricht, sept 2013 
$\checkmark$ Jansen M, Burhenne K, Middelweerd M. Hoge hakken in de klei. Verankering van de Academische Werkplaatsen Publieke Gezondheid kansrijk in een ondernemende GGD. AWPG-GGD Zuid Limburg, nov 2014 ISBN:978-90-9028591-7

$\checkmark$ Janssen N, Evers SMAA, Ruwaard D, Spreeuwenberg C, Jansen MWJ. Effectevaluatie en economische evaluatie Voor Elkaar in Parkstad. Universiteit Maastricht, vakgroep Health Services Research, Maastricht 2015

$\checkmark$ Kaljouw M, van Vliet K. Naar nieuwe zorg en zorgberoepen, de contouren. Zorginstituut Nederland, 2015

$\checkmark \quad$ Kramer D, Maas J, Wingen M, Kunst AE. Neighbourhood safety and leisure-time physical activity among Dutch adults: a multilevel perspective. International Journal of Behavior, Nutrition and Physical Activity 2013;10:11. doi:10.1186/1479-5868-10-11

$\checkmark \quad$ Kramer D, Stronks K, Maas J, Wingen M, Kunst AE. Social neighborhood environment and sports participation among Dutch adults: Does sports location matter? Scandinavian Journal of Medicine \& Science in Sports 2015;25(2):273-279

$\checkmark$ Kuipers MAG, de Korte R, Soto Rojas VE, Richter M, Moor I, Rimpelä A, Perelman J, Federico $B$, Kunst AE, Lorant $\mathrm{V}$. School smoking policies and educational inequalities in smoking behavior among 14 to17 year old adolescents in Europe. Submitted

$\checkmark \quad$ Mackenbach JP (red). Successen van preventive 1970-2010. Erasmus Publishing, Erasmus MC, Rotterdam 2011

$\checkmark$ Mental Health Foundation. The Lonely Society. London: Mental Health Foundation, 2010.

$\checkmark$ Ministerie van Volksgezondheid, Welzijn en Sport. Betrouwbare publieke gezondheid: Gezamenlijke verantwoordelijkheid van gemeenten en Rijk. Kenmerk 629287-122954-PG. Den Haag, VWS 2014

$\checkmark$ Ministerie van Volksgezondheid, Welzijn en Sport. Alles is gezondheid. Het Nationaal Programma Preventie 2014 - 2016. Den Haag, Rijksoverheid 2013

$\checkmark$ Putrik P, De Vries NK, Mujakovic S, Van Amelsvoort L, Kant IJ, Kunst AE, Van Oers JAM, Jansen MWJ. Living environment matters: relationships between neighborhood characteristics and health of the residents in a Dutch municipality. Journal of Community Health, 2014, June 12; doi 10.1007/s10900-014-9894-y

$\checkmark \quad$ RIVM, Centrum Gezondheid en Maatschappij (G\&M). https://www.volksgezondheidenzorg.info/ranglijsten RIVM, Bilthoven 2015a (laatst gecheckt 15 maart 2015)

$\checkmark \quad$ RIVM. http://www.nationaalkompas.nl/gezondheid-en-ziekte/sterfte-levensverwachting-endaly-s/gezonde-levensverwachting/de-gezonde-levensverwachting-samengevat/ RIVM, Bilthoven 2015b (laatst gecheckt 15 maart 2015)

$\checkmark \quad$ RIVM. http://www.zorgatlas.nl/thema-s/gebiedsindelingen-entopografie/gebiedsindelingen/ggd-regio-s 2015c (laatst gecheckt 21 april 2015)

$\checkmark$ Rose G. Strategy of prevention: lessons from cardiovascular disease. British Medical Journal 1981;282:1847-51.

$\checkmark$ Rose G. Retiteration: Sick individuals and sick populations. International Journal of Epidemiology. 2001 Jun;30(3):427-32

$\checkmark$ Rose G. Sick individuals and sick populations. International Journal of Epidemiology. 1985;14:32-38

$\checkmark$ Ruijsbroek A, Droomers M,Groenewegen PP, Hardyns W, Stronks K. Social safety,self-rated general health and physical activity: Changes in area crime, area safety feelings and the role of social cohesion. Health \&Place31(2015)39-45

$\checkmark$ Schayck CP, Jansen MWJ. De Gezonde Basisschool van de toekomst. Kennis/As Limburg, Movare, GGD Zuid Limburg. Universiteit Maastricht, 2013

$\checkmark$ Schelleman-Offermans K, Tietschert M, Derickx M, Ruwaard D, Jansen MWJ. Wijkgericht werken en integrale zorg. De kijk van eerstelijnszorgprofessionals, gemeenten, zorgverzekeraars en patiënten op het integreren van gemeentelijke basiszorg en eerstelijnszorg. Maastricht University, GGD Zuid Limburg, 2015 ISBN 978-90-823808-0-4 
$\checkmark \quad$ Shor E, Roelfs DJ, Bugyi P, Schwartz JE. Meta-analysis of marital dissolution and mortality: reevaluating the intersection of gender and age. Soc Sci Med, 2012;75:46-59

$\checkmark$ Steenbakkers M, Vermeer AJM, Janssen-Goffin MJH, Hajema KJ. Een nieuwe kijk op gezondheid in Zuid-Limburg. Regionaal Rapport Volksgezondheid Toekomst Verkenning 2014. GGD Zuid Limburg, Geleen 2014

$\checkmark \quad$ Stijnen MMN, Van Hoof MS, Wijnands-Hoekstra IYM, Guldemond-Hecker Y, Duimel-Peeters IGP, Vrijhoef HJM, Jansen MWJ. Detected health and well-being problems following comprehensive geriatric assessment during a home visit among community-dwelling older people: who benefits most? Family Practice 2014, 1-8 doi:10.1093/fampra/cmu015

$\checkmark$ Stijnen MMN. Towards proactive care for potentially frail older people in general practice. Development, feasibility, and effectiveness of the [G]OLD preventive home visitation programma. $\mathrm{PhD}$ thesis. Maastricht University, 2015

$\checkmark \quad$ Van Kann DHH, Kremers SPJ, Bartelink NHM, Gubbels JS, de Vries SI, de Vries NK, Jansen MWJ. The association between the physical environment of primary schools and active school transport. Environment \& Behaviour. 2014 Jan 27th DOI: 10.1177/0013916513519644

$\checkmark$ Vyncke V, De Clercq B, Stevens V, Costongs C, Barbareschi G, Jónsson SH, Darias Curvo S, Kebza V, Currie C, Maes L. Does neighbourhood social capital aid in levelling the social gradient in the health and well-being of children and adolescents? A literature review. BMC Public Health 2013;13:65 http://www.biomedcentral.com/1471-2458/13/65 